\title{
Chitosan as a Coating for Biocontrol in Postharvest Products: A Bibliometric Review
}

\author{
Ma de la Paz Salgado-Cruz ${ }^{1,2}$, Julia Salgado-Cruz ${ }^{3}$, Alitzel Belem García-Hernández ${ }^{1}$, \\ Georgina Calderón-Domínguez ${ }^{1}{ }^{1}$, Hortensia Gómez-Viquez ${ }^{3}$, Rubén Oliver-Espinoza ${ }^{3}$, \\ María Carmen Fernández-Martínez ${ }^{4}$ and Jorge Yáñez-Fernández ${ }^{4, *}$ (D)
}

check for

updates

Citation: Salgado-Cruz, M.d.1.P.; Salgado-Cruz, J.; García-Hernández, A.B.; Calderón-Domínguez, G.; Gómez-Viquez, H.; Oliver-Espinoza, R.; Fernández-Martínez, M.C.; Yáñez-Fernández, J. Chitosan as a Coating for Biocontrol in Postharvest Products: A Bibliometric Review. Membranes 2021, 11, 421. https:// doi.org/10.3390/membranes11060421

Academic Editor: Fabrice Gouanvé

Received: 27 April 2021

Accepted: 21 May 2021

Published: 31 May 2021

Publisher's Note: MDPI stays neutral with regard to jurisdictional claims in published maps and institutional affiliations.

Copyright: (c) 2021 by the authors. Licensee MDPI, Basel, Switzerland. This article is an open access article distributed under the terms and conditions of the Creative Commons Attribution (CC BY) license (https:// creativecommons.org/licenses/by/ $4.0 /)$.
1 Escuela Nacional de Ciencias Biológicas, Instituto Politécnico Nacional, Ciudad de México 07738, Mexico; mdlpsalgadocr@conacyt.mx (M.d.1.P.S.-C.); agarciah1805@alumno.ipn.mx (A.B.G.-H.); gcalderon@ipn.mx (G.C.-D.)

2 Consejo Nacional de Ciencia y Tecnología (CONACYT), Ciudad de México 03940, Mexico

3 Centro de Investigaciones Económicas, Administrativas y Sociales, Instituto Politécnico Nacional, Ciudad de México 11360, Mexico; jsalgado@ipn.mx (J.S.-C.); hgomezv@ipn.mx (H.G.-V.); roliver@ipn.mx (R.O.-E.)

4 Laboratorio de Biotecnología Alimentaria, Unidad Profesional Interdisciplinaria de Biotecnología, Instituto Politécnico Nacional, Ciudad de México 07340, Mexico; mfernandezm@ipn.mx

* Correspondence: jyanezfe@ipn.mx

\begin{abstract}
The aim of this work was to carry out a systematic literature review focused on the scientific production, trends, and characteristics of a knowledge domain of high worldwide importance, namely, the use of chitosan as a coating for postharvest disease biocontrol in fruits and vegetables, which are generated mainly by fungi and bacteria such as Aspergillus niger, Rhizopus stolonifera, and Botrytis cinerea. For this, the analysis of 875 published documents in the Scopus database was performed for the years 2011 to 2021. The information of the keywords' co-occurrence was visualized and studied using the free access VOSviewer software to show the trend of the topic in general. The study showed a research increase of the chitosan and nanoparticle chitosan coating applications to diminish the postharvest damage by microorganisms (fungi and bacteria), as well as the improvement of the shelf life and quality of the products.
\end{abstract}

Keywords: chitosan; coating; biocontrol; postharvest; fruit; vegetables

\section{Introduction}

The most effective and used edible coatings for the protection of fruits and vegetables are made up one or more natural polymers such as cellulose [1], alginate [2], gellan [3], pectin, starch and its derivatives [4], methylcellulose, carboxymethylcellulose [5], Arabic gum [6], whey protein concentrate [7], and chitosan or chitosan nanoemulsion [8,9]. Chitosan is a deacetylated form of chitin, (poly $\beta-(1 \rightarrow 4) \mathrm{N}$-acetyl-d-glucosamine), and is the second most abundant biopolymer found in nature after cellulose, with prominent film-forming properties, non-toxicity, biodegradable and biocompatible properties, high mechanical strength, and excellent antimicrobial activity [10], and it has been used as a coating in various foods [11]. Furthermore, chitosan has been approved by the United States Food and Drug Administration (USFDA) as a food additive and listed as generally recognized as safe (GRAS) in the USA and Japan $[6,10]$.

In the last years, chitosan has gained more attention from researchers due to its broadspectrum activity and high destruction rate against Gram-positive and Gram-negative bacteria [12] and filamentous fungi [13-15]. However, its quality, chemical and biological properties, and therefore its applications are closely related to numerous intrinsic and extrinsic factors such as the degree of deacetylation (DD) [16,17], molecular weight, viscosity, sources, and extraction pathway [18]. Chitosan is a polysaccharide mainly obtained from invertebrates; insect cuticles; fungal cell walls; green algae; yeast; crustacean shells 
such as those of cockles, shrimp, crabs, etc.; by chemical (alkaline hydrolysis with $\mathrm{NaOH}$ solutions) and other less-used methods such as alkaline treatment at high temperature and high pressure [19]; or a process that uses ultrasound [20-22] and sometimes, less frequently, enzymatic deacetylation [23]. Moreover, it is important to mention that the method used increases or decreases the deacetylation degree (DD) and determines the content of free amino groups and the cationic character [24].

On the other hand, the DD grade of chitosan indicates the number of acetyl groups removed from chitin, which corresponds to the release of the amino groups from the $\mathrm{N}$-acetylglucosamine monomers. In this regard, He et al. [25] mentioned the chitosan classification according to its DD as being low between 55 and $70 \%$, medium between 70 and $85 \%$, high between 85 and 95\%, and ultra-high between 95 and $100 \%[25,26]$. In this case, Kong et al. [27] found that the chitosan microspheres with a $63.6 \%$ degree of deacetylation (DD) exhibited the highest antibacterial activity concerning the microspheres made with chitosan at $83.7 \%$ of DD, which exerted at least some antibacterial activity.

Furthermore, although the antifungal or antimicrobial mechanism of action of chitosan is still being studied, some hypotheses have already been proposed, e.g., Yang [28] mentioned that this polymer permeates and perforates the fungus nuclei, the protein cell membranes, and intracellular constituents, inactivating bacterial metabolism due to the presence of an amino group that has a positive charge with a $\mathrm{pH}$ lower than 6.3 and interacts with negative charges of the cell wall of microorganisms, generating the rupture or lysis of these structures, causing the loss of protein compounds and other intracellular constituents [29]. However, because there are still many factors that need to be analyzed during the coating process such as the coating suspensions properties, the fruit surface microstructure and wettability [1], and the synergy between biocontrol agents and natural bioactive compounds, it is necessary that more studies be conducted [30].

On the other hand, due to the vast amount of existing information, an "intoxication" problem can be generated, as reported by Flórez-Martínez et al. (2021) [31]. Consequently, in this paper, we carried out a bibliometric analysis to show and quantify the evolution of the research, perspectives, challenges, and prospects, not only a cross-sectional study, as this provides limited information.

\section{Biobliometric Analysis}

\subsection{Steps of Bibliometric Analysis}

\subsubsection{Methodology of Data Collection}

Data for this research were collected from the Scopus database, specifically on 14 April 2021, covering 10 years from 2011 to 2021. For this, a Boolean search string was used. First, the search was realized for those coming from the relevant keyword fields (e.g., chitosan, postharvest, biocontrol, fungi, and phytopathogens). Subsequently, the Scopus service was used, with the option to combine searches, using the "Combine queries" field, where the syntax applied is the \# symbol with the "OR" and "AND" operators. The Scopus database query was as follows: ((TITLE-ABS-KEY (chitosan)) AND (TITLE-ABS-KEY (coatings))) AND ((TITLE-ABS-KEY (postharvest OR post-harvest)) OR (TITLE-ABS-KEY (fungal AND diseases)) OR (TITLE-ABS-KEY (biocontrol)) OR (TITLE-ABS-KEY (phytopathogens)) OR (TITLE-ABS-KEY (fungi)) OR (TITLE-ABS-KEY (mould)) OR (TITLE-ABS-KEY (bacterial))) AND (LIMIT-TO (PUBYEAR, 2021) OR LIMIT-TO (PUBYEAR, 2020) OR LIMIT-TO (PUBYEAR, 2019) OR LIMIT-TO (PUBYEAR, 2018) OR LIMIT-TO (PUBYEAR, 2017) OR LIMIT-TO (PUBYEAR, 2016) OR LIMIT-TO (PUBYEAR, 2015) OR LIMIT-TO (PUBYEAR, 2014) OR LIMIT-TO (PUBYEAR, 2013) OR LIMIT-TO (PUBYEAR, 2012) OR LIMIT-TO (PUBYEAR, 2011)) AND (LIMIT-TO (DOCTYPE, “ar")) AND (EXCLUDE (EXACTKEYWORD, "Human")) AND (EXCLUDE (EXACTKEYWORD, "Animal")) AND (LIMIT-TO (LANGUAGE, "English")) AND (EXCLUDE (EXACTKEYWORD, “Titanium")) AND (EXCLUDE (EXACTKEYWORD, "Biomedical Applications")); in order to limit the topic additional phrases, (AND (LIMIT-TO (EXACTKEYWORD, "Fruits"))) was added into the query string, which resulted in 92 articles [32,33]. 


\subsubsection{Methodology of Analysis, Identification and Obtaining Map}

The total number of searches resulted in 875 publications (from January 2011 to 14 April 2021). The raw data obtained (CSV Format) from Scopus was analyzed using the VOSviewer software (www.vosviewer.com, accessed on 25 March 2021; Van Eck and Waltman, 2009-2020, version 1.6.15, Leiden University, Leiden, The Netherlands) for the construction and bibliometric visualization of networks of institutions, countries, keywords, and citations per article.

\subsubsection{Methodology of Analysis of Further Analysis}

SigmaPlot ${ }^{\circledR}$ software (SigmaPlot 12.0, Systat Software, Inc. SigmaPlot for Windows. San Jose, CA, USA) was used to design and produce the graph shown in Figure 1; then, the "Dynamic fit wizard" plugin was applied for curve fitting, using a linear regression model. The obtained equation was Equation (1).

$$
f=y_{0}+a * x
$$

where $Y=$ response (number of published papers); $x=$ years; $a=$ the line's slope, a parameter that describes the steepness of the curve; and $y_{0}=$ intercept.

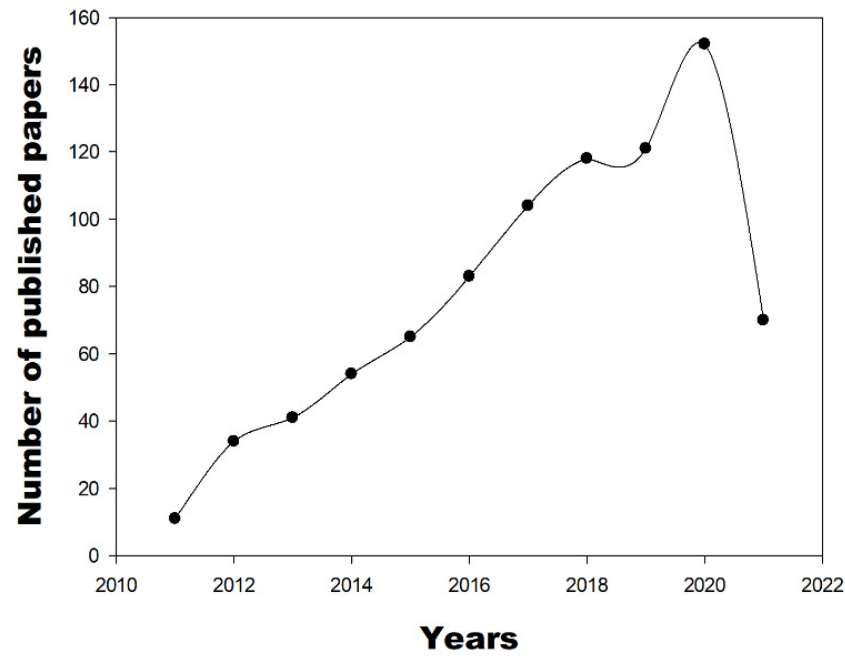

(A)

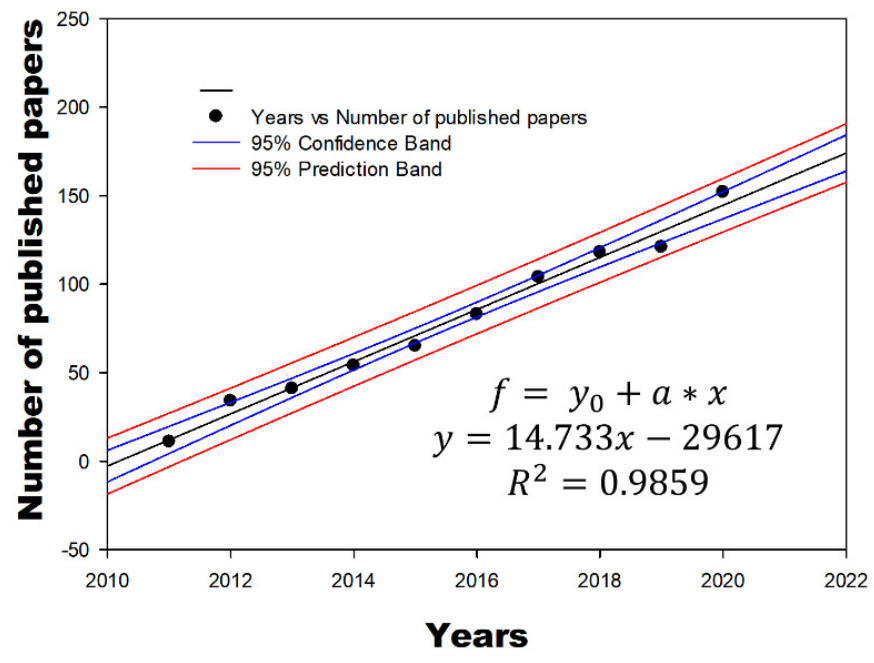

(B)

Figure 1. (A) Number of articles in Scopus from 2011 to 2021 in the field of the use and applications of postharvest chitosan products. (B) Fitted linear trend for the number of publications.

\section{Results}

\subsection{Scientific Production Period}

Figure 1 shows the number of scientific publications per year, limiting this research to a period from January 2011 to 14 April 2021. It can be observed that the temporal evolution between the number of articles versus years, in this field of research, has had linear growth in the last decade. This data indicates that researchers have focused on increasing the number of publications on this topic due to the use of chitosan coatings as a preservation technique potentially decreasing antimicrobial and antifungal activity when applied to different fruits and vegetables. From 2011 to 2013, few documents per year were published on the subject $(11,34$, and 41 , respectively), but these have increased. It should be noted that the year 2021 only covered the period until April. In order to perform the data analysis and have it be explained by a linear regression model using the best fit $\left(R^{2}=0.9859\right)$ of the results, we did not consider this year and only included studies until the year 2020, as shown in Figure 1. According to the equation obtained for the year 2021, 
158 or 159 published documents are forecast. However, it is an issue that requires intensive research, and therefore a greater number of publications on the topic is expected.

\subsection{Keyword Analysis}

In all published documents, the central focus of an article is highlighted using keywords, which are essential and facilitate mapping for readers [32] so that their analysis is necessary. One method is by word cloud (Figure 2), which provides a first view of the dataset, allowing us to explore and visually analyze, as well as to size and create the first classification for our data. The size of the words "chitosan" and "coatings" suggests that in most research, these words have been the most persistent theme. However, this technique only provides qualitative information, and therefore it is necessary to execute a more in-depth analysis.

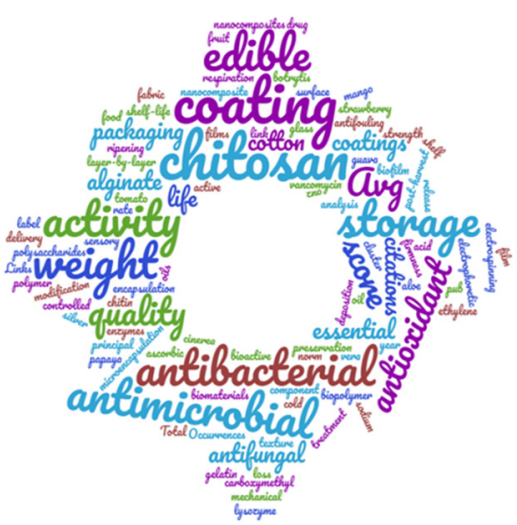

Figure 2. Word cloud extracted from nubedepalabras.es.

A more accurate method is the co-keyword cluster mapping (Figure 3), obtained from author keywords. Here, the software (VOSviewer) analyzed the 84 most frequently terms, and each one of them was repeated at least six times. It is imperative to mention that each circle represents a keyword, and its size indicates its appearance frequency in the articles. Data analysis generated nine clusters marked with different colors, e.g., the first cluster (in red) contained 19 terms, with "chitosan" being the most frequent term, with a greater node keyword, closely associated with the 81 terms belonging at the nine clusters, but mainly with largest nodes such as "edible coating, coating, shelf life, antibacterial activity".

VOSViewer software can also reflect the trend, impact and evolutionary process of the topic's high-frequency keywords involving "chitosan" and its many applications. The overlay display map, showing the gradient color from blue to yellow, indicated the average citation score of a keyword reported by Guo et al. [34] (Figure 4). It is important to note that the node's color also determined when the term or keyword was introduced for the first time in the network [14]. Our analysis allowed us to visualize the fact that these issues will continue to take hold in the future. In particular, it was observed that from 2019, the topics "shelf life, preservation, nanoparticles" and "antibacterial properties" began to gain greater importance. These results could be significant for the scientific development research that involves the topic of food waste that generates so many economic losses. On the other hand, the most important group of terms is related to studies where the co-occurrence network is present for words such as "edible coating", "antifungal", "postharvest", and "antibacterial or antimicrobial activity". These words seem to be an issue related to increasing the shelf life of fruits and vegetables, as shown in the literature review carried out in Section 3.4. The most important terms in the keyword map can be an idea generator for researchers. For example, the generation of coatings involved added nanoparticles for protection and longer shelf life of different foods. However, much research is still needed to establish the existing interactions between food matrices and these coatings. 


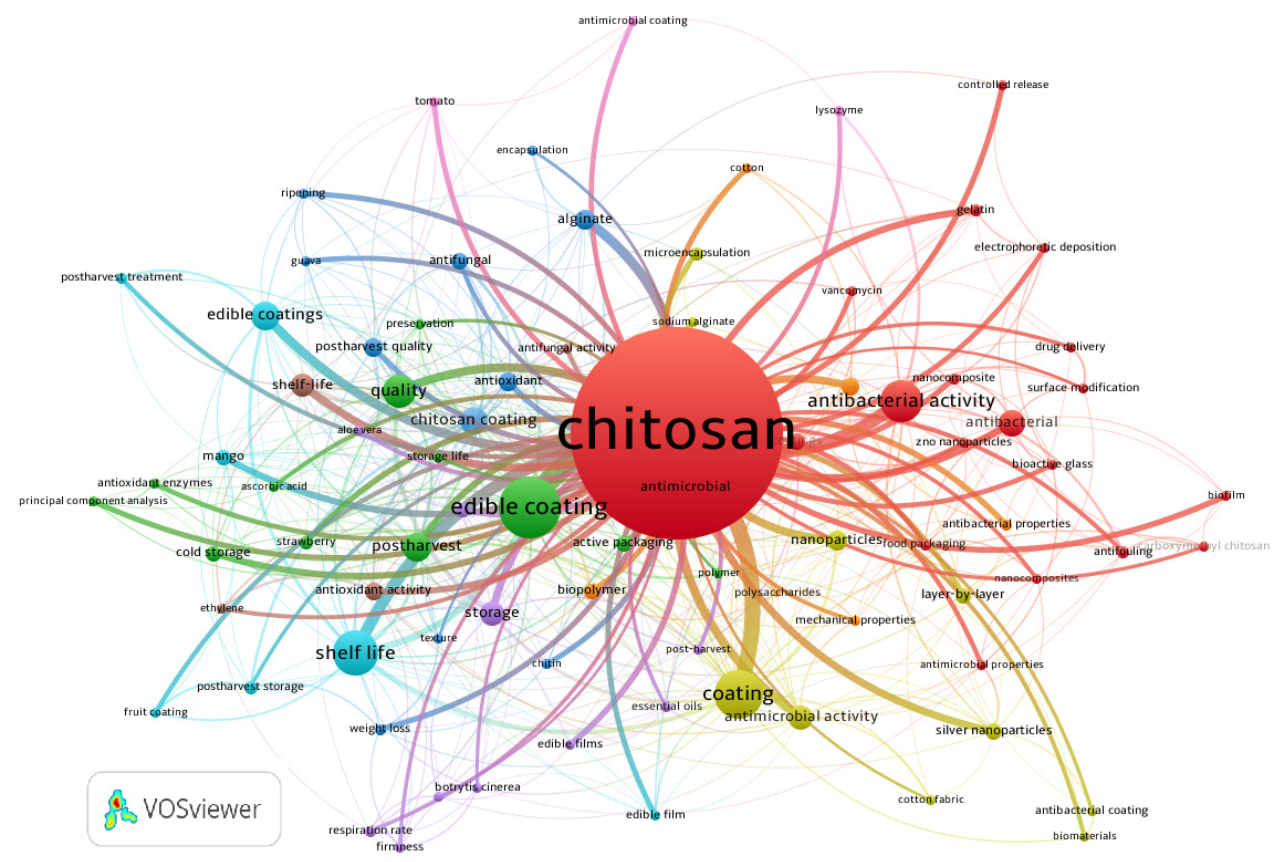

Item: Chitosan | Cluster: 1 | Links:81 | Total strenght: 284.00 | Ocurrence: 371

Figure 3. Map of co-occurrence network visualization based on article weights for the terms related with the first group.

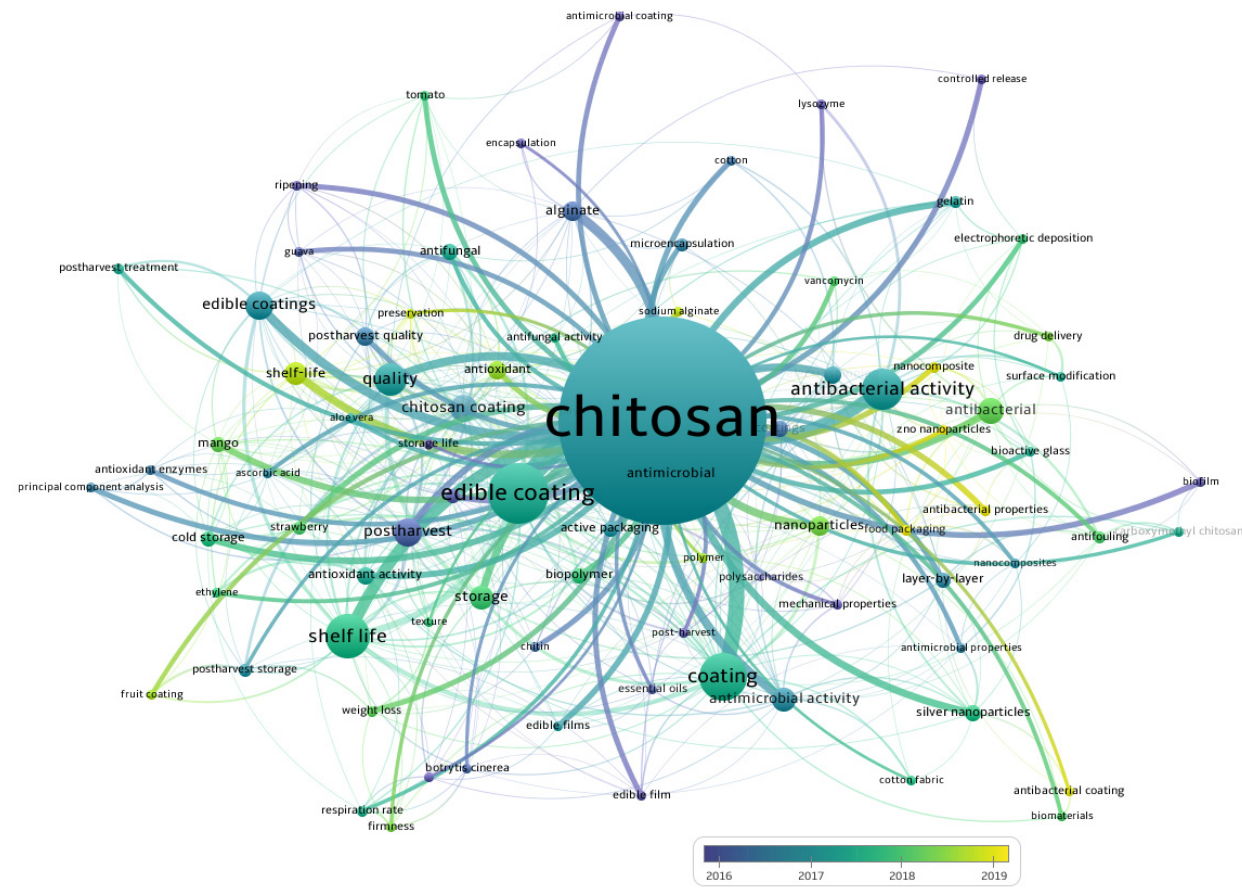

Item: Chitosan | Cluster: 1| Links: 81 | Total link strength: 284:00 | Ocurrences: 371 | Avg. pub. year: 2017.01

Figure 4. Map of co-overlay visualization of author keywords from 2010 to 2021.

On the other hand, as shown in Figure 4, the keyword "chitosan", highlighted with the larger circle in blue, also determined a central position, indicating its importance and direct connection with other smaller nodes such as "fruit coating", "useful life", "strawberry", "mango", "guava", "tomato", and "papaya". Terms that gain importance as will be seen later. 


\subsection{Keyword the Top 20 Most-Cited Documents}

On the other hand, Table 1 shows the top 20 most-cited articles, extracted from the search of 875 documents. Obtained data such as the year of publication, authorship, journal title, publication count, and citation count were analyzed. Due to the high quantity of published papers, our analysis focused on the most highly cited papers and those related to the keyword "fruits", which generated 92 documents, analyzed as described in Tables 2-4.

Table 1. The top of 20 most cited authors and documents between 2011 and 2021 .

\begin{tabular}{|c|c|c|c|c|}
\hline Document Title/Journal & Total Citations & Cite Score 2019 & $\begin{array}{c}\text { Journal's } \\
\text { Impact Factor }\end{array}$ & Reference \\
\hline $\begin{array}{c}\text { Antimicrobial activity of iron oxide nanoparticle upon } \\
\text { modulation of nanoparticle-bacteria interface/Scientific } \\
\text { Reports }\end{array}$ & 258 & 7.2 & 4.576 & {$[35]$} \\
\hline $\begin{array}{c}\text { Oxidative stress induced by inorganic nanoparticles in } \\
\text { bacteria and aquatic microalgae-State of the art and } \\
\text { knowledge gaps/Nanotoxicology }\end{array}$ & 202 & 11.5 & 4.925 & [36] \\
\hline $\begin{array}{l}\text { Development of noncytotoxic chitosan-gold nanocomposites } \\
\text { as efficient antibacterial materials / ACS Applied Materials and } \\
\text { Interfaces }\end{array}$ & 152 & 13.6 & 8.758 & {$[37]$} \\
\hline $\begin{array}{l}\text { Antimicrobial Electrospun Biopolymer Nanofiber Mats } \\
\text { Functionalized with Graphene Oxide-Silver } \\
\text { Nanocomposites/ACS Applied Materials and Interfaces }\end{array}$ & 146 & 13.6 & 8.758 & [38] \\
\hline $\begin{array}{c}\text { Chitosan and chitosan-ZnO-based complex nanoparticles: } \\
\text { Formation, characterization, and antibacterial } \\
\text { activity / Journal of Materials Chemistry B }\end{array}$ & 125 & 8.8 & 5.344 & [39] \\
\hline $\begin{array}{c}\text { Effect of chitosan coatings on the physicochemical } \\
\text { characteristics of Eksotika II papaya (Carica papaya L.) fruit } \\
\text { during cold storage/Food Chemistry }\end{array}$ & 218 & 10.7 & 6.306 & {$[40]$} \\
\hline $\begin{array}{c}\text { Effect of hydroxypropylmethylcellulose and chitosan } \\
\text { coatings with and without bergamot essential oil on quality } \\
\text { and safety of cold-stored grapes/Postharvest Biology and } \\
\text { Technology }\end{array}$ & 196 & 7.8 & 4.303 & [41] \\
\hline $\begin{array}{l}\text { Advanced physico-chemical characterization of chitosan by } \\
\text { means of TGA coupled on-line with FTIR and GCMS: } \\
\text { Thermal degradation and water adsorption } \\
\text { capacity/Polymer Degradation and Stability }\end{array}$ & 192 & 6.8 & 4.032 & [42] \\
\hline $\begin{array}{l}\text { Development of edible bioactive coating based on modified } \\
\text { chitosan for increasing the shelf life of strawberries/Food } \\
\text { Research International }\end{array}$ & 166 & 6.2 & 4.972 & [43] \\
\hline $\begin{array}{l}\text { Effects of chitosan coating on postharvest life and quality of } \\
\text { guava (Psidium guajava L.) fruit during cold storage/Scientia } \\
\text { Horticulturae }\end{array}$ & 162 & 3.7 & 2.769 & [44] \\
\hline $\begin{array}{c}\text { Production and evaluation of dry alginate-chitosan } \\
\text { microcapsules as an enteric delivery vehicle for probiotic } \\
\text { bacteria/Biomacromolecules }\end{array}$ & 158 & 10 & 6.092 & [45] \\
\hline $\begin{array}{l}\text { Effect of chitosan edible coating on the quality of double } \\
\text { filleted Indian oil sardine (Sardinella longiceps) during chilled } \\
\text { storage/Food Hydrocolloids }\end{array}$ & 155 & 10.6 & 7.053 & [46] \\
\hline $\begin{array}{c}\text { Antimicrobial edible films and coatings for fresh and } \\
\text { minimally processed fruits and vegetables: A review/Critical } \\
\text { Reviews in Food Science and Nutrition }\end{array}$ & 154 & 7.862 & 13.2 & [47] \\
\hline
\end{tabular}


Table 1. Cont

\begin{tabular}{|c|c|c|c|c|}
\hline Document Title/Journal & Total Citations & Cite Score 2019 & $\begin{array}{c}\text { Journal's } \\
\text { Impact Factor }\end{array}$ & Reference \\
\hline $\begin{array}{c}\text { Effect of chitosan-based edible coating on antioxidants, } \\
\text { antioxidant enzyme system, and postharvest fruit quality of } \\
\text { strawberries (Fragaria } \times \text { aranassa Duch.)/LWT-Food Science } \\
\text { and Technology }\end{array}$ & 152 & 6.4 & 4.006 & [48] \\
\hline $\begin{array}{c}\text { Antimicrobial activity of chitosan, organic acids and } \\
\text { nano-sized solubilisates for potential use in smart } \\
\text { antimicrobially-active packaging for potential food } \\
\text { applications / Food Control }\end{array}$ & 146 & 8.4 & 4.258 & [49] \\
\hline $\begin{array}{l}\text { Comparison of chitosan-gelatin composite and bilayer } \\
\text { coating and film effect on the quality of refrigerated rainbow } \\
\text { trout/Food Chemistry }\end{array}$ & 120 & 10.7 & 6.306 & {$[50]$} \\
\hline $\begin{array}{l}\text { Antimicrobial effectiveness of bioactive packaging materials } \\
\text { from edible chitosan and casein polymers: Assessment on } \\
\text { carrot, cheese, and salami/Journal of Food Science }\end{array}$ & 118 & 3.7 & 2.478 & [51] \\
\hline $\begin{array}{l}\text { Effect of chitosan-aloe vera coating on postharvest quality of } \\
\text { blueberry (Vaccinium corymbosum) fruit/ Postharvest Biology } \\
\text { and Technology }\end{array}$ & 117 & 7.8 & 4.303 & [52] \\
\hline $\begin{array}{l}\text { Survivability of probiotics encapsulated in alginate gel } \\
\text { microbeads using a novel impinging aerosols } \\
\text { method/International Journal of Food Microbiology }\end{array}$ & 113 & 7.4 & 4.187 & [53] \\
\hline $\begin{array}{c}\text { Effects of carboxymethyl cellulose and chitosan bilayer } \\
\text { edible coating on postharvest quality of citrus } \\
\text { fruit/Postharvest Biology and Technology }\end{array}$ & 109 & 7.8 & 4.303 & [54] \\
\hline
\end{tabular}

It should be noted that the 20 most-cited articles were all published between 2011 and 2015, with a citation range from 109 to 258, where the highest rated was Arakha et al. (2015) [35]. This study was published in Scientific Reports and intended to explore the interaction pattern role of the iron oxide nanoparticle (IONP)-bacteria interface that enhances the antimicrobial activity of IONP using positively charged chitosan. In analyzing the rest of the authors and the most cited scientific papers in the domain under study, we noted the importance of the use of chitosan and its multiple applications as well as their effect as a coating in various fruits. In this sense, the second most cited document [40] reported the use of chitosan as an effective control in reducing weight loss, maintaining firmness, delayed changes in the peel color, and soluble solids in papaya (Carica papaya L.), which is one of the most important fruit crops in the world and has a short post-harvest life. However, it did not study the damage by opportunistic plant pathogens capable of producing diseases or loss of crops, which has led to countless studies, as shown in Tables 2-4.

It is worth noting that the emerging interdisciplinary field of nanotechnology has been a recurring phenomenon in recent studies, as shown in Table 1, with the highest cited document or the documents published by various authors [36-39].

\subsection{Review of Documents with Keyword "Fruits"}

Exceptionally, the co-occurrence between keywords allows for the generation of knowledge in search of a common goal. Over the past decade, researchers around the world have developed many different methods to minimize postharvest fruit loss because they have the highest waste rates of any food product ( $45 \%$ waste [55]), which is a global problem. A novel method is the use of chitosan coatings as well as their different combinations with other polymers or with essential oils or nanoparticles, among others, as shown in Table 2. This allows for the storage period to be increased in order to postpone the deterioration of 
fruits and vegetables and preventing the growth of microorganisms transmitted by food on the surfaces of the products.

Table 2. Fungi that affect postharvest fruit quality: analysis from 2011 to 2021.

\begin{tabular}{|c|c|c|c|c|}
\hline Fungi & Disease or Damage & Fruit & Coatings & Reference \\
\hline Aspergillus niger ${ }^{\mathrm{A}}$ & Gray mold & \multirow{4}{*}{$\begin{array}{c}\text { Strawberry (Fragaria } \\
\text { ananassa) }\end{array}$} & $\begin{array}{l}\text { Chitosan incorporated with olive } \\
\text { oil residues }\end{array}$ & {$[56]$} \\
\hline Rhizopus stolonifera ${ }^{\mathrm{B}}$ & $\begin{array}{l}\text { Brown spots and } \\
\text { softening by rotting }\end{array}$ & & $\begin{array}{l}\text { Chitosan as gel, nanoscale } \\
\text { particles or nanocomposite }\end{array}$ & [13] \\
\hline \multirow{4}{*}{ Botrytis cinerea $^{\mathrm{C}}$} & \multirow{4}{*}{ Black mold (black rot) } & & $\begin{array}{l}\text { Coatings with cellulose, chitin, } \\
\text { and chitosan nanomaterials }\end{array}$ & [1] \\
\hline & & & $\begin{array}{c}\text { Chitosan functionalized by } \\
\text { acylation with palmitoyl chloride } \\
\text { and essential oils of limonene and } \\
\text { peppermint }\end{array}$ & {$[43]$} \\
\hline & & $\begin{array}{l}\text { Blueberries and cherry } \\
\text { tomatoes }\end{array}$ & $\begin{array}{l}\text { Chitosan thymol nanoparticles } \\
\text { prepared by ionic gelation }\end{array}$ & [57] \\
\hline & & Cherry tomatoes & $\begin{array}{l}\text { Thymol nanoemulsions } \\
\text { incorporated in quinoa } \\
\text { protein/chitosan edible films }\end{array}$ & {$[58]$} \\
\hline \multirow[b]{2}{*}{ P. expansum } & \multirow{3}{*}{ Blue mold } & & Heating at $38{ }^{\circ} \mathrm{C}$ and $1 \%$ chitosan & [59] \\
\hline & & $\begin{array}{l}\text { Apples (Malus domestica } \\
\text { Borkh. cv. Gala) }\end{array}$ & $\begin{array}{c}\text { Chitosan (medium molecular } \\
\text { weight with } 60 \% \text { or more } \\
\text { deacetylated) }\end{array}$ & {$[60]$} \\
\hline P. citrinum & & $\begin{array}{l}\text { Lingwu long jujube } \\
\text { fruit }\end{array}$ & Chitosan and cinnamon oil & {$[61]$} \\
\hline \multirow{2}{*}{ Alternaria alternate } & \multirow{2}{*}{ Black mold } & $\begin{array}{l}\text { Pitaya (Stenocereus } \\
\text { griseus H.) }\end{array}$ & Chitosan + oleic acid & {$[62]$} \\
\hline & & $\begin{array}{c}\text { Bell pepper } \\
\text { (Capsicumannuum L.) }\end{array}$ & $\begin{array}{l}\text { Chitosan nanoparticles with } \\
\alpha \text {-pinene }\end{array}$ & [63] \\
\hline \multirow{7}{*}{$\begin{array}{l}\text { Colletotrichum } \\
\text { gloeosporioides }\end{array}$} & \multirow{7}{*}{ Anthracnose } & $\begin{array}{l}\text { Guava (Psidium guajava } \\
\text { L.) }\end{array}$ & Chitosan-citric acid & {$[64]$} \\
\hline & & $\begin{array}{c}\text { Papaya (Carica papaya } \\
\text { L.) }\end{array}$ & $\begin{array}{l}\text { Chitosan and Mentha villosa Huds } \\
\text { or M. piperita L. essential oil }\end{array}$ & {$[65,66]$} \\
\hline & & \multirow{3}{*}{$\begin{array}{l}\text { Mango (Mangifera } \\
\text { indica L.) }\end{array}$} & Chitosan with thyme oil & [67] \\
\hline & & & $\begin{array}{l}\text { Vanillin-chitosan and zeolite or } \\
\text { activated carbon }\end{array}$ & {$[68]$} \\
\hline & & & $\begin{array}{c}\text { Chitosan, carboxymethyl cellulose, } \\
\text { and vanillin }\end{array}$ & [69] \\
\hline & & $\begin{array}{l}\text { Avocado (Persea } \\
\text { americana) }\end{array}$ & $\begin{array}{l}\text { Chitosan nanoparticles and } \\
\text { chitosan biocomposites with } \\
\text { pepper tree essential oil }\end{array}$ & [70] \\
\hline & & $\begin{array}{c}\text { Papaya (Carica papaya } \\
\text { L.) }\end{array}$ & Aloe vera-chitosan composite & [71] \\
\hline Colletotrichum fragariae & Anthracnose crown rot & $\begin{array}{l}\text { Strawberry (Fragaria } \\
\text { ananassa Duch) }\end{array}$ & $\begin{array}{l}\text { Chitosan functionalized with } \\
\text { cinnamon essential oil and } \\
\text { aqueous extract of Roselle calyces }\end{array}$ & [72] \\
\hline Aspergillus flavus & $\begin{array}{l}\text { Production of } \\
\text { aflatoxins }\end{array}$ & Fig fruit & $\begin{array}{c}\text { Chitosan and propolis } \\
\text { nanoparticles }\end{array}$ & [8] \\
\hline
\end{tabular}


Table 2. Cont.

\begin{tabular}{ccccc}
\hline Fungi & Disease or Damage & Fruit & Coatings & Reference \\
\hline Fusarium solani & Lesions on roots & $\begin{array}{c}\text { Cucumber (Cucumis } \\
\text { sativus L.) }\end{array}$ & $\begin{array}{c}\text { Nanostructured chitosan and } \\
\text { chitosan functionalized with } \\
\text { cinnamon essential oil or } \\
\text { trans-cinnamaldehyde }\end{array}$ \\
\hline Fusarium oxysporum & Wilt & Watermelon (Citrullus & lanatus) & $\begin{array}{c}\text { Chitosan-mesoporous silica } \\
\text { nanoparticle }\end{array}$ \\
\hline Burkholderia seminalis & Fruit rot & Apricot fruit & Acid-soluble and water-soluble \\
chitosan
\end{tabular}

The letters correspond to the fungi worked by each author: Letter A, B, and C correspond to [13]; letter B corresponds to [56], and letter C corresponds to [1].

It was observed that there is plenty of research involving published studies concerning the antimicrobial and antifungal activity of chitosan as well as a combination with other polymers or the application of different essential oils against foodborne pathogens. However, of the total reports ( 875 documents published), only 93 documents with the keyword "fruits" were analyzed due to the importance of this kind of food. The findings mentioned below and those in Tables $2-5$ correspond to these documents.

Table 3. Published results of bacterial contamination by different microorganisms in fruits: from 2011 to 2021.

\begin{tabular}{|c|c|c|c|}
\hline Bacteria & Fruit & Coatings & Reference \\
\hline \multirow{2}{*}{$\begin{array}{l}\text { Staphylococcus aureus, Escherichia coli, } \\
\text { and Bacillus subtilis. }\end{array}$} & Snake fruit, Salacca zalacca & Glucomannan-beeswax-chitosan & [75] \\
\hline & Bananas (Musa acuminata L.) & $\begin{array}{l}\mathrm{ZnO} \text { nanoparticles incorporated into } \\
\text { chitosan/Arabic gum }\end{array}$ & {$[6]$} \\
\hline $\begin{array}{c}\text { Staphylococcus aureus, Listeria } \\
\text { monocytogenes, Pseudomonas } \\
\text { aeruginosa, Salmonella spp., } \\
\text { Escherichia coli }\end{array}$ & Grapes & Chitosan nanoparticles & [76] \\
\hline $\begin{array}{l}\text { E. coli, S. aureus, B. subtilis, and } M . \\
\text { guilliermondii. }\end{array}$ & Mango (Mangifera indica L.) & $\begin{array}{l}\text { Ferulic acid-grafted chitosan using } \\
\text { recombinant bacterial laccase from } \\
\text { Bacillus vallismortis }\end{array}$ & [28] \\
\hline $\begin{array}{l}\text { Salmonella typhimurium, total } \\
\text { mesophilic aerobes, yeasts, and molds }\end{array}$ & $\begin{array}{l}\text { Grape berries (Vitis vinifera L. } \\
\quad \times \text { V. labruscana Bailey) }\end{array}$ & Lemongrass oil-chitosan emulsion & [77] \\
\hline $\begin{array}{l}\text { Staphylococcus aureus, Escherichia coli, } \\
\text { Listeria innocua }\end{array}$ & $\begin{array}{l}\text { Watermelon, melon, } \\
\text { strawberries }\end{array}$ & $\begin{array}{l}\text { Nanoparticles of vanillin are formed } \\
\text { in situ from an aqueous/ethane } \\
\text { solution and deposited on the surface } \\
\text { of chitosan, using a high-intensity } \\
\text { ultrasonic method }\end{array}$ & [78] \\
\hline Staphylococcus aureus, Escherichia coli & Bananas & $\begin{array}{l}\text { Carboxymethyl cellulose on } \\
\text { quaternized chitosan } \\
\text { (2-N-hydroxypropyl-3- } \\
\text { trimethylammonium chloride } \\
\text { chitosan, HTCC) }\end{array}$ & [79] \\
\hline $\begin{array}{c}\text { Bacillus cereus, B. subtilis, and Serratia } \\
\text { marcescens }\end{array}$ & Mangaba fruits & $\begin{array}{l}\text { Cassava starch, chitosan, and Myrcia } \\
\text { ovata Cambessedes essential oils }\end{array}$ & [80] \\
\hline Escherichia coli O157:H7 & Cherry tomato & Chitosan with Artemisia annua oil & [81] \\
\hline
\end{tabular}


Table 4. Published results from bacterial and fungal contamination by different microorganisms in fruits: from 2011 to 2021.

\begin{tabular}{|c|c|c|}
\hline \multicolumn{3}{|c|}{ Psychrophilic Bacterial, Mesophilic Aerobic, Yeast, and Mold } \\
\hline Apricot fruits (Prunus armeniaca L. cultivar Rival) & Chitosan enriched with pomegranate peel extract & [9] \\
\hline Blueberry fruit (Vacciniumashei L.) & $\begin{array}{c}\text { Chitosan with nano-material films such as silicon and } \\
\text { titanium dioxides }\end{array}$ & [82] \\
\hline Blueberry (Vaccinium corymbosum) & $\begin{array}{c}\text { Chitosan/nano-titanium dioxide and chitosan/nano-titanium } \\
\text { dioxide (tween-thymol) }\end{array}$ & [83] \\
\hline Black mulberry (Morus nigra) & Chitosan and cassava starch & [84] \\
\hline Tomato (Solanum lycopersicum L.) & Chitosan-Ruta graveolens essential oil coatings & [85] \\
\hline Cucumber (Cucumis sativus L.) & Nanoparticles and Zataria multiflora essential oil & [86] \\
\hline Strawberries (Fragaria ananassa cv. Camarosa) & $\begin{array}{l}\text { Natamycin, nisin, pomegranate, and grape seed extract in } \\
\text { chitosan }\end{array}$ & [87] \\
\hline Strawberries & Chitosan-monomethyl fumaric acid & [88] \\
\hline \multirow[b]{2}{*}{ Fresh-cut apple slices } & Chitosan and stevia & [89] \\
\hline & $\begin{array}{l}110 \text { and } 300 \mathrm{~nm} \text { chitosan nanoparticles or chitosan dissolved } \\
\text { in } 2 \% \text { citric acid }\end{array}$ & [90] \\
\hline Fig (Ficus carica L.) & Chitosan, thymol, and their combination & [91] \\
\hline Tomatoes (Lycopersicon esculentum Mill.) & $\begin{array}{c}\text { Cassava starch-chitosan enriched with Lippia sidoides Cham. } \\
\text { essential oil and pomegranate peel extract }\end{array}$ & [92] \\
\hline Kiwifruits (Actinidia deliciosa cv. Hayward) & $\begin{array}{l}\text { Aloe vera, chitosan (formulated with acetic or citric acid), and } \\
\text { sodium alginate }\end{array}$ & [93] \\
\hline Guava (Psidium guajava L.) & $\begin{array}{c}\text { Chitosan-cassava starch coatings containing a mixture of } \\
\text { Lippia gracilis Schauer genotypes }\end{array}$ & [94] \\
\hline Wolfberry (Lycium barbarum L. cv. Ningqi No. 1) & Hot water dip at $42{ }^{\circ} \mathrm{C}$ for $30 \mathrm{~min}$ and $1 \%$ chitosan & [95] \\
\hline \multicolumn{3}{|c|}{ Molds and Yeasts } \\
\hline Tomato (Lycopersicon esculentum) & Chitosan $\mathrm{b}$ enriched with pequi peel extract & [96] \\
\hline \multirow{2}{*}{ Strawberries $($ Fragaria $\times$ ananassa $)$} & Peony extracts (Paeonia rockii) dispersed in chitosan & [97] \\
\hline & Quinoa protein-chitosan-sunflower oil & [98] \\
\hline
\end{tabular}

Recently, the impact of preharvest foliar spraying with chitosan and postharvest aloe vera gel coating (AVG) on the quality of table grapes during storage was evaluated, thereby extending the shelf life of the fruit up to 15 days by significantly reducing the decomposition index [99]. The relevance of this study marks an important stage in the supply chain (pre-harvest) in which there is little research. Another recent finding is the production of edible coating films based on Pickering emulsions, which showed a smaller droplet size, narrower size distribution, and improved stability. These could inhibit the growth of typical spoilage organisms such as S. aureus and E. coli in order to preserve fruits and vegetables [100]. In 2020, Jung et al. [101] applied this method by adding oleic acid and cellulose nanocrystal in "Bartlett" pears (Pyrus communis L.) for delaying ripening and superficial scald during the long-term cold storage.

Tables $2-4$ show studies concerning the application of chitosan as an antimicrobial and antifungal to maintain fruit and vegetable quality at the postharvest stage. It is highlighted that several studies have focused on reducing the antifungal activity of Aspergillus niger, Rhizopus stolonifera, Botrytis cinerea, P. expansum, Alternaria alternate, Colletotrichum gloeosporioides, etc. In some studies, the antifungal activity of chitosan depends on the extraction procedure, the deacetylation percentage, molecular weight, or the microstructure of the fruit and the interaction of the coating material.

Some fruits such as strawberries $[1,13,43,48,56,72,87,98,102-104]$, mango (Mangifera indica L.) $[28,68,105-109]$, tomato $[58,81,85,92,96,110-113]$, guava $[64,94,114]$, banana $[6,79,108]$, 
apples $[59,60,115,116]$, or fresh-cut apple slices $[89,90]$ are especially perishable and therefore there is a larger number of documents focused on decreasing mechanical injury, desiccation, decay, and physiological disorders during storage [43], as observed in Tables 2-5. In this sense, the most cited document (166 citations) [43] mentioned that the use of chitosan functionalized by acylation with palmitoyl chloride increase its hydrophobicity in order to ensure a controlled release and improve its stability and adherence in strawberries. Notwithstanding, research in this area is still incipient, and therefore is necessary to carry out future research about the topic with other fruits or in different matrixes of food.

For this purpose, mixtures of chitosan and some other materials have also been used, as shown in Table 5; these results indicated that the coatings could reduce the damage in different fruits or vegetables.

Moreover, other studies have addressed that the chitosan coating applied in pummelo fruit mitigates the development of juice sac granulation and delays postharvest senescence in the same fruit during room temperature storage [117], and in eggplant cultivars (purple long, purple round, and white long), chitosan was effective in minimizing weight loss, maintained quality, and prolonged storability with good appearance and overall acceptability [118]. However, it is necessary to conduct more research focused on combinations of adequate techniques and different coating materials that consider the intrinsic and extrinsic factors that affect food, as well as allowing for enhancement of shelf life and decreases in the amount of waste.

Table 5. Coating materials mixture with chitosan applied to extend the shelf-life and improve the quality of fruits.

\begin{tabular}{|c|c|c|c|}
\hline Fruit & Coatings & Results & Reference \\
\hline Le Conte pears & Chitosan-beeswax-based & $\begin{array}{l}\text { The use of coatings improved quality } \\
\text { parameters by successfully showing a } \\
\text { decrease in weight loss, deterioration, and } \\
\text { softening rate. }\end{array}$ & [119] \\
\hline \multirow[t]{3}{*}{ Strawberries } & $\begin{array}{l}\text { Chitosan and apple peel } \\
\text { polyphenols composite }\end{array}$ & $\begin{array}{l}\text { The weight loss, decay percentage, and } \\
\text { senescence were reduced and maintained } \\
\text { quality attributes of the fruits during } \\
\text { storage. }\end{array}$ & [120] \\
\hline & Chitosan-whey protein isolate & $\begin{array}{l}\text { A considerable reduction in color indices, } \\
\text { weight loss, pH, and titratable acidity; } \\
\text { reduction in sugars, ascorbic acid, and total } \\
\text { phenolics was noted. }\end{array}$ & [102] \\
\hline & $\begin{array}{l}\text { Three different forms of chitosan by } \\
\text { decoloration method, without the } \\
\text { decoloration step and the } \\
\text { deproteinization step }\end{array}$ & $\begin{array}{l}\text { Chitosan coatings delayed changes in } \\
\text { weight loss and the appearance of fungal } \\
\text { infection. }\end{array}$ & [103] \\
\hline $\begin{array}{l}\text { Strawberries (Fragaria } \times \\
\text { ananassas Duchesne ex Rozier } \\
\text { 'Earliglow') }\end{array}$ & $\begin{array}{l}\text { Chitosan solutions of } 0.5,1.0 \text {, and } \\
\qquad 1.5 \mathrm{~g} / 100 \mathrm{~mL}\end{array}$ & $\begin{array}{l}\text { Coatings can maintain high antioxidant } \\
\text { levels and high-antioxidant enzyme } \\
\text { activities and inhibit increased oxidative } \\
\text { enzyme activity to reduce moisture loss } \\
\text { and delay senescence. }\end{array}$ & [48] \\
\hline $\begin{array}{c}\text { Strawberries (Fragaria } \times \\
\text { ananassa cv. Camarosa) }\end{array}$ & Chitosan-lemon essential oil & $\begin{array}{l}\text { Pure chitosan promoted the formation of } \\
\text { esters and dimethyl furfural, while } \\
\text { coatings containing lemon essential oil } \\
\text { incorporated terpenes (limonene, } \\
\gamma \text {-terpinene, p-cymene, and } \alpha \text {-citral) to the } \\
\text { volatiles of the fruit and improved the } \\
\text { fermentation process, modifying the } \\
\text { typical fruit aroma composition. }\end{array}$ & [104] \\
\hline
\end{tabular}


Table 5. Cont.

\begin{tabular}{|c|c|c|c|}
\hline Fruit & Coatings & Results & Reference \\
\hline \multirow[t]{3}{*}{ Mango (Mangifera indica L.) } & $\begin{array}{l}\text { Chitosan-aloe vera gels and } \\
\text { calcium chloride }\left(\mathrm{CaCl}_{2}\right)\end{array}$ & $\begin{array}{l}\text { The results showed a decrease in weight } \\
\text { loss, reduction of ascorbic acid, and } \\
\text { inhibition of polyphenol oxidase (PPO) } \\
\text { activity during the storage period. }\end{array}$ & [105] \\
\hline & $\begin{array}{c}\text { Chitosan-cinnamon essential oil } \\
\text { microcapsules }\end{array}$ & $\begin{array}{l}\text { Multilayer coatings made by electrostatic } \\
\text { interaction on mangoes slowed down the } \\
\text { increase in weight loss and preserved } \\
\text { firmness under storage conditions. }\end{array}$ & [106] \\
\hline & Chitosan $(1,2$, or $3 \%)$ & $\begin{array}{c}\text { Chitosan delayed the climacteric peak, } \\
\text { water loss, firmness, and sugar content, as } \\
\text { well as decreasing starch degradation, and } \\
\text { it was also observed to affect basic } \\
\text { mitochondrial respiration. }\end{array}$ & [107] \\
\hline
\end{tabular}

Chitosan, gallic acid, and chitosan gallate

The coatings delayed ripening and weight

loss and maintained a higher peel

membrane stability index as well as the

quality of the 'Hindi-Besennara' mangoes during 2 weeks of shelf life.

The film-forming properties of chitosan were influenced by molecular weight and significantly affected the postharvest quality of mango fruit during storage.

The coating prolongs the shelf life and inhibits oxidative enzymes, specifically Apricots Alginate, chitosan, and gellan gum peroxidase (POD) and polyphenol oxidase (PPO).

Chitosan suppressed respiratory rate, fresh weight loss, firmness, and skin color with delayed degradation of chlorophyll.

The coating is effective in maintaining less weight loss, having more firmness and slowing the nutraceutical loss that occurs in the postharvest, mainly of the carotenoid lycopene.

Palm stearin, palm kernel olein

Cherry tomato (PSPKOo), and chitosan of different degrees of deacetylation (DD) (85 and $95 \%$ )

Chinese kiwifruit (Actinidia chinensis Planch)
Chitosan enriched with salicylic acid

Chitosan film with 85\% DD (MW 300,000

Da) and $31 \%$ PSPKOo blend was the most effective in reducing weight loss and maintaining firmness and redness.

The treatment significantly maintained texture and color, inhibited moisture loss and acidity change, and delayed the decomposition of vitamin $\mathrm{C}$ and soluble solids.

Chitosan with some olive waste extracts of leaf and pomace extracts

Apple (Malus domestica var. Anna)

Apples (cv. Golab Kohanz)
Nanochitosan emulsion ( 0.2 and $0.5 \%)$
Chitosan coating films significantly reduced the gradual decrease in total phenolics, flavonoids, and antioxidants, and relatively improved the nutritional quality of apple during postharvest.

The effect of nanochitosan coating was shown to meaningfully reduce the weight loss, respiration rate, ethylene production, and peroxidase activity of the samples compared to the control. 
Table 5. Cont.

\begin{tabular}{|c|c|c|c|}
\hline Fruit & Coatings & Results & Reference \\
\hline $\begin{array}{l}\text { Longan fruit (Dimocarpus } \\
\text { longan) }\end{array}$ & $\begin{array}{l}\text { UV-C irradiation and carrageenan } \\
\text { and chitosan-based coating }\end{array}$ & $\begin{array}{l}\text { The application of UV treatment followed } \\
\text { by chitosan coating was the best treatment } \\
\text { combination for control enzyme activities } \\
\text { and reduced the rate of senescence. }\end{array}$ & [122] \\
\hline $\begin{array}{c}\text { Pomegranate (Punica granatum } \\
\text { L.) }\end{array}$ & $\begin{array}{c}\text { Resin wax (Britex Ti), carnauba wax } \\
\text { (Xedasol M14), and chitosan (1 and } \\
2 \% w / v)\end{array}$ & $\begin{array}{l}\text { The coated fruits showed significantly } \\
\text { lower respiration rate and weight loss, but } \\
\text { the carnauba wax was able to maintain } \\
\text { considerably higher fruit quality and } \\
\text { bioactive compounds. }\end{array}$ & [123] \\
\hline $\begin{array}{c}\text { Carambola (Averrhoa carambola } \\
\text { L.) }\end{array}$ & Chitosan, Arabic gum, and alginate & $\begin{array}{l}\text { The coated fruits showed a significant } \\
\text { delay in the change of weight loss, } \\
\text { percentage of decomposition, accumulation } \\
\text { of sugar, degradation of pigments, and } \\
\text { content of ascorbic acid, maintaining the } \\
\text { highest concentration of total phenols. }\end{array}$ & [124] \\
\hline Tomatoes & $\begin{array}{l}\text { Ultrasound-assisted chitosan } \\
\text { surfactant nanostructure (micelle } \\
\text { sizes of } 400,600, \text { and } 800 \mathrm{~nm})\end{array}$ & $\begin{array}{l}\text { The treatment enhanced the phenolic } \\
\text { content while maintaining a lower } \\
\text { respiration level throughout most of the } \\
\text { storage duration. However, the weight loss } \\
\text { was greater in the treated fruits. }\end{array}$ & [112] \\
\hline \multirow[t]{2}{*}{$\begin{array}{l}\text { Grape (Vitis vinifera }(V . \\
\text { vinifera) })\end{array}$} & Putrescine alone or with chitosan & $\begin{array}{c}\text { The chitosan-putrescine combination } \\
\text { reduced weight loss, incidence of decay, } \\
\text { browning, and berry breakage and } \\
\text { cracking. }\end{array}$ & [125] \\
\hline & Chitosan $(0.5$ or $1 \%)$ & $\begin{array}{l}\text { The treated berries showed less weight loss, } \\
\text { decay, browning, shattering, and cracking. }\end{array}$ & [126] \\
\hline $\begin{array}{l}\text { Longan (Dimocarpus longan } \\
\text { Lour.) }\end{array}$ & $\begin{array}{l}\text { Chitosan/nano-silica hybrid } \\
\text { filmusing tetraethoxysilane as } \\
\text { precursor }\end{array}$ & $\begin{array}{l}\text { The film remarkably prolonged shelf life, } \\
\text { reduced browning index, delayed weight } \\
\text { loss, and inhibited the increase in } \\
\text { malondialdehyde amount and } \\
\text { polyphenoloxidase activity in fresh fruit. }\end{array}$ & [127] \\
\hline $\begin{array}{l}\text { Tomato fruit (Lycopersicon } \\
\text { Esculentum) }\end{array}$ & $\begin{array}{l}\text { Chitosan and a chitosan derivative } \\
\text { (N,O-carboxymethyl chitosan) }\end{array}$ & $\begin{array}{l}\text { The coating can extend the shelf life and } \\
\text { improve the quality of tomato fruit by } \\
\text { delaying ripening, reducing weight loss, } \\
\text { and preserving the fruit firmness. }\end{array}$ & [113] \\
\hline $\begin{array}{c}\text { Yali pears (Pyrus bretschneideri } \\
\text { Rehd.) }\end{array}$ & Chitosan $(1.5 \%)$ & $\begin{array}{l}\text { Chitosan treatments both before and after } \\
\text { damage delayed the color changes caused } \\
\text { by damage, inhibited increase disease } \\
\text { incidence, and improved the bruise } \\
\text { recovery during the storage. }\end{array}$ & [128] \\
\hline Papaya (Carica papaya L.) & $\begin{array}{l}\text { Chitosan (95\% deacetylated; } 0.5,1.0 \\
1.5, \text { and } 2.0 \% w / v)\end{array}$ & $\begin{array}{l}\text { Chitosan provided effective control to } \\
\text { reduce weight loss, maintained firmness, } \\
\text { and delayed changes in the peel color and } \\
\text { soluble solids concentration during } 5 \\
\text { weeks of storage. }\end{array}$ & {$[40]$} \\
\hline
\end{tabular}

\section{Conclusions}

This bibliometric review analyzed the evolutionary process over the past decade of topics about chitosan as coating and their fruits and vegetables' antifungal or antimicrobial effects. VOSviewer software is a useful and versatile tool that allows for easy visualization and analysis of bibliometric networks. In this paper, 875 documents reported that coatings made of chitosan only or chitosan in combination with other biopolymers are a natural and safe post-harvest biocontrol strategy to decrease microbial spoilage mainly by pre- 
and post-harvest diseases, reducing the damage of fruits as well as extending their shelf life. Finally, this work can provide a useful perspective for future research in the studied field since it demonstrates the existence of an emerging area of study that is intended to reduce a global problem caused by the generation of agro-industrial waste due to the loss of post-harvest damaged crops.

Author Contributions: Conceptualization, M.d.1.P.S.-C., J.S.-C., A.B.G.-H. and G.C.-D.; methodology, H.G.-V., R.O.-E. and J.Y.-F.; software, H.G.-V. and R.O.-E.; validation, J.Y.-F. and G.C.-D.; formal analysis, M.d.1.P.S.-C. and J.S.-C.; investigation, A.B.G.-H.; resources, J.Y.-F., R.O.-E. and H.G.-V.; data curation, J.S.-C.; writing-original draft preparation, M.d.1.P.S.-C.; writing-review and editing, A.B.G.-H., M.C.F.-M. and J.Y.-F.; supervision, M.d.1.P.S.-C., R.O.-E. and G.C.-D. All authors have read and agreed to the published version of the manuscript.

Funding: This research received no external funding.

Institutional Review Board Statement: Not applicable.

Informed Consent Statement: Not applicable.

Data Availability Statement: Not applicable.

Acknowledgments: This study was supported by Instituto Politécnico Nacional (IPN), as well as by CATEDRAS Conacyt program.

Conflicts of Interest: The authors declare no conflict of interest.

\section{References}

1. Sun, X.; Wu, Q.; Picha, D.H.; Ferguson, M.H.; Ndukwe, I.E.; Azadi, P. Comparative performance of bio-based coatings formulated with cellulose, chitin, and chitosan nanomaterials suitable for fruit preservation. Carbohydr. Polym. 2021, 259, 117764. [CrossRef]

2. Arroyo, B.J.; Bezerra, A.C.; Oliveira, L.L.; Arroyo, S.J.; de Melo, E.A.; Santos, A.M.P. Antimicrobial active edible coating of alginate and chitosan add ZnO nanoparticles applied in guavas (Psidium guajava L.). Food Chem. 2020, 309, 125566. [CrossRef]

3. Morsy, N.; Rayan, A.M. Effect of different edible coatings on biochemical quality and shelf life of apricots (Prunus armenica L. cv Canino). J. Food Meas. Charact. 2019, 13, 3173-3182. [CrossRef]

4. Bello-Lara, J.E.; De Nayarit, U.A.; Balois-Morales, R.; Juarez-Lopez, P.; Alia-Tejacal, I.; Peña-Valdivia, C.B.; Jiménez-Zurita, J.O.; Sumaya-Martínez, M.T.; Jiménez-Ruíz, E.I.; Universidad Autónoma del Estado de Morelos; et al. Coatings based on starch and pectin from 'Pear' banana (Musa ABB), and chitosan applied to postharvest 'Ataulfo' mango fruit. Rev. Chapingo Ser. Hortic. 2016, 22, 209-218. [CrossRef]

5. Baswal, A.K.; Dhaliwal, H.S.; Singh, Z.; Mahajan, B.; Kalia, A.; Gill, K.S. Influence of carboxy methylcellulose, chitosan and beeswax coatings on cold storage life and quality of Kinnow mandarin fruit. Sci. Hortic. 2020, 260, 108887. [CrossRef]

6. La, D.D.; Nguyen-Tri, P.; Le, K.H.; Nguyen, P.T.; Nguyen, M.D.-B.; Vo, A.T.; Chang, S.W.; Tran, L.D.; Chung, W.J.; Nguyen, D.D. Effects of antibacterial $\mathrm{ZnO}$ nanoparticles on the performance of a chitosan/gum arabic edible coating for post-harvest banana preservation. Prog. Org. Coat. 2021, 151, 106057. [CrossRef]

7. Simonaitiene, D.; Brink, I.; Šipailienè, A.; Leskauskaite, D. The effect of chitosan and whey proteins-chitosan films on the growth ofPenicillium expansumin apples. J. Sci. Food Agric. 2014, 95, 1475-1481. [CrossRef] [PubMed]

8. Aparicio-García, P.F.; Ventura-Aguilar, R.I.; Del Río-García, J.C.; Hernández-López, M.; Guillén-Sánchez, D.; Salazar-Piña, D.A.; Ramos-García, M.d.L.; Bautista-Baños, S. Edible Chitosan/Propolis Coatings and Their Effect on Ripening, Development of Aspergillus flavus, and Sensory Quality in Fig Fruit, during Controlled Storage. Plants 2021, 10, 112. [CrossRef]

9. Gull, A.; Bhat, N.; Wani, S.M.; Masoodi, F.A.; Amin, T.; Ganai, S.A. Shelf life extension of apricot fruit by application of nanochitosan emulsion coatings containing pomegranate peel extract. Food Chem. 2021, 349, 129149. [CrossRef] [PubMed]

10. Hosseinnejad, M.; Jafari, S.M. Evaluation of different factors affecting antimicrobial properties of chitosan. Int. J. Biol. Macromol. 2016, 85, 467-475. [CrossRef] [PubMed]

11. Kritchenkov, A.S.; Egorov, A.R.; Kurasova, M.N.; Volkova, O.V.; Meledina, T.V.; Lipkan, N.A.; Tskhovrebov, A.G.; Kurliuk, A.V.; Shakola, T.V.; Dysin, A.P.; et al. Novel non-toxic high efficient antibacterial azido chitosan derivatives with potential application in food coatings. Food Chem. 2019, 301, 125247. [CrossRef]

12. Kong, M.; Chen, X.G.; Xing, K.; Park, H.J. Antimicrobial properties of chitosan and mode of action: A state of the art review. Int. J. Food Microbiol. 2010, 144, 51-63. [CrossRef] [PubMed]

13. Melo, N.F.C.B.; de Lima, M.A.B.; Stamford, T.L.M.; Galembeck, A.; Flores, M.A.; Takaki, G.M.D.C.; Medeiros, J.A.D.C.; StamfordArnaud, T.M.; Stamford, T.C.M. In vivo and in vitro antifungal effect of fungal chitosan nanocomposite edible coating against strawberry phytopathogenic fungi. Int. J. Food Sci. Technol. 2020, 55, 3381-3391. [CrossRef]

14. Barbosa, M.W. Uncovering research streams on agri-food supply chain management: A bibliometric study. Glob. Food Secur. 2021, 28, 100517. [CrossRef] 
15. Istúriz-Zapata, M.; Hernández-López, M.; Correa-Pacheco, Z.; Barrera-Necha, L. Quality of cold-stored cucumber as affected by nanostructured coatings of chitosan with cinnamon essential oil and cinnamaldehyde. LWT 2020, 123, 109089. [CrossRef]

16. Liu, C.X.; Chen, G.H.; Sun, M.K.; Fan, J.S.; Hua, Z. Determination of the degree of deacetylation of chitosan by multiwave-length linear regression UV spectrophotometry. J. Ocean. Univ. Qingdao 2003, 33, 148-154.

17. Zhang, Y.; Zhang, X.; Ding, R.; Zhang, J.; Liu, J. Determination of the degree of deacetylation of chitosan by potentiometric titration preceded by enzymatic pretreatment. Carbohydr. Polym. 2011, 83, 813-817. [CrossRef]

18. Xia, W.; Liu, P.; Zhang, J.; Chen, J. Biological activities of chitosan and chitooligosaccharides. Food Hydrocoll. 2011, 25, 170-179. [CrossRef]

19. Abdou, E.S.; Nagy, K.S.; Elsabee, M.Z. Extraction and characterization of chitin and chitosan from local sources. Bioresour. Technol. 2008, 99, 1359-1367. [CrossRef]

20. Kittur, F.S.; Harish Prashanth, K.V.; Udaya Sankar, K.; Tharanathanm, R.N. Characterization of chitin, chitosan and their carboxymethyl derivatives by differential scanning calorimetry. Carbohydr. Polym. 2002, 49, 185-193. [CrossRef]

21. Berger, L.R.R.; Stamford, T.C.M.; De Oliveira, K.; Árabe, R.; Pessoa, A.D.M.P.; De Lima, M.A.B.; Pintado, M.M.; Câmara, M.P.S.; Franco, L.D.O.; Magnani, M.; et al. Chitosan produced from Mucorales fungi using agroindustrial by-products and its efficacy to inhibit Colletotrichum species. Int. J. Biol. Macromol. 2018, 108, 635-641. [CrossRef] [PubMed]

22. Gonil, P.; Sajomsang, W. Applications of magnetic resonance spectroscopy to chitin from insect cuticles. Int. J. Biol. Macromol. 2012, 51, 514-522. [CrossRef] [PubMed]

23. EL Knidri, H.; Dahmani, J.; Addaou, A.; Laajeb, A.; Lahsini, A. Rapid and efficient extraction of chitin and chitosan for scale-up production: Effect of process parameters on deacetylation degree and molecular weight. Int. J. Biol. Macromol. 2019, 139, 1092-1102. [CrossRef]

24. Weißpflog, J.; Vehlow, D.; Müller, M.; Kohn, B.; Scheler, U.; Boye, S.; Schwarz, S. Characterization of chitosan with different degree of deacetylation and equal viscosity in dissolved and solid state-Insights by various complimentary methods. Int. J. Biol. Macromol. 2021, 171, 242-261. [CrossRef] [PubMed]

25. He, X.; Li, K.; Xing, R.; Liu, S.; Hu, L.; Li, P. The production of fully deacetylated chitosan by compression method. Egypt. J. Aquat. Res. 2016, 42, 75-81. [CrossRef]

26. Tavares, L.; Flores, E.E.E.; Rodrigues, R.C.; Hertz, P.F.; Noreña, C.P.Z. Effect of deacetylation degree of chitosan on rheological properties and physical chemical characteristics of genipin-crosslinked chitosan beads. Food Hydrocoll. 2020, $106,105876$. [CrossRef]

27. Kong, M.; Chen, X.-G.; Xue, Y.-P.; Liu, C.; Yu, L.-J.; Ji, Q.-X.; Cha, D.S.; Park, H.J. Preparation and antibacterial activity of chitosan microshperes in a solid dispersing system. Front. Mater. Sci. China 2008, 2, 214-220. [CrossRef]

28. Yang, J.; Sun, J.; An, X.; Zheng, M.; Lu, Z.; Lu, F.; Zhang, C. Preparation of ferulic acid-grafted chitosan using recombinant bacterial laccase and its application in mango preservation. RSC Adv. 2018, 8, 6759-6767. [CrossRef]

29. Tantala, J.; Thumanu, K.; Rachtanapun, C. An assessment of antibacterial mode of action of chitosan on Listeria innocua cells using real-time HATR-FTIR spectroscopy. Int. J. Biol. Macromol. 2019, 135, 386-393. [CrossRef]

30. Yang, Y.; Ge, L. Sensor coating employed to preliminarily evaluate the banana ripeness. Colloids Surf. A Physicochem. Eng. Asp. 2021, 616, 126057. [CrossRef]

31. Flórez-Martínez, D.H.; Contreras-Pedraza, C.A.; Rodríguez, J. A systematic analysis of non-centrifugal sugar cane processing: Research and new trends. Trends Food Sci. Technol. 2021, 107, 415-428. [CrossRef]

32. Hamidah, I.; Pawinanto, R.E.; Mulyanti, B.; Yunas, J. A bibliometric analysis of micro electro mechanical system energy harvester research. Heliyon 2021, 7, e06406. [CrossRef] [PubMed]

33. Khudzari, J.M.; Kurian, J.; Tartakovsky, B.; Raghavan, G. Bibliometric analysis of global research trends on microbial fuel cells using Scopus database. Biochem. Eng. J. 2018, 136, 51-60. [CrossRef]

34. Guo, Y.-M.; Huang, Z.-L.; Guo, J.; Guo, X.-R.; Li, H.; Liu, M.-Y.; Ezzeddine, S.; Nkeli, M.J. A bibliometric analysis and visualization of blockchain. Future Gener. Comput. Syst. 2021, 116, 316-332. [CrossRef]

35. Arakha, M.; Pal, S.; Samantarrai, D.; Panigrahi, T.K.; Mallick, B.C.; Pramanik, K.; Mallick, B.; Jha, S. Antimicrobial activity of iron oxide nanoparticle upon modulation of nanoparticle-bacteria interface. Sci. Rep. 2015, 5, 14813. [CrossRef] [PubMed]

36. Von Moos, N.; Slaveykova, V.I. Oxidative stress induced by inorganic nanoparticles in bacteria and aquatic microalgae-state of the art and knowledge gaps. Nanotoxicology 2013, 8, 605-630. [CrossRef] [PubMed]

37. Regiel-Futyra, A.; Kus-Liśkiewicz, M.; Sebastian, V.; Irusta, S.; Arruebo, M.; Stochel, G.; Kyzioł, A. Development of Noncytotoxic Chitosan-Gold Nanocomposites as Efficient Antibacterial Materials. ACS Appl. Mater. Interfaces 2015, 7, 1087-1099. [CrossRef]

38. De Faria, A.F.; Perreault, F.; Shaulsky, E.; Chavez, L.H.A.; Elimelech, M. Antimicrobial Electrospun Biopolymer Nanofiber Mats Functionalized with Graphene Oxide-Silver Nanocomposites. ACS Appl. Mater. Interfaces 2015, 7, 12751-12759. [CrossRef]

39. Perelshtein, I.; Ruderman, Y.; Perkas, N.; Tzanov, T.; Beddow, J.; Joyce, E.; Mason, T.J.; Blanes, M.; Mollá, K.; Patlolla, A.; et al. Chitosan and chitosan-ZnO-based complex nanoparticles: Formation, characterization, and antibacterial activity. J. Mater. Chem. B 2013, 1, 1968-1976. [CrossRef]

40. Ali, A.; Muhammad, M.T.M.; Sijam, K.; Siddiqui, Y. Effect of chitosan coatings on the physicochemical characteristics of Eksotika II papaya (Carica papaya L.) fruit during cold storage. Food Chem. 2011, 124, 620-626. [CrossRef] 
41. Sánchez-González, L.; Pastor, C.; Vargas, M.; Chiralt, A.; González-Martínez, C.; Cháfer, M. Effect of hydroxypropylmethylcellulose and chitosan coatings with and without bergamot essential oil on quality and safety of cold-stored grapes. Postharvest Biol. Technol. 2011, 60, 57-63. [CrossRef]

42. Corazzari, I.; Nisticò, R.; Turci, F.; Faga, M.G.; Franzoso, F.; Tabasso, S.; Magnacca, G. Advanced physico-chemical characterization of chitosan by means of TGA coupled on-line with FTIR and GCMS: Thermal degradation and water adsorption capacity. Polym. Degrad. Stab. 2015, 112, 1-9. [CrossRef]

43. Vu, K.; Hollingsworth, R.; Leroux, E.; Salmieri, S.; Lacroix, M. Development of edible bioactive coating based on modified chitosan for increasing the shelf life of strawberries. Food Res. Int. 2011, 44, 198-203. [CrossRef]

44. Hong, K.; Xie, J.; Zhang, L.; Sun, D.; Gong, D. Effects of chitosan coating on postharvest life and quality of guava (Psidium guajava L.) fruit during cold storage. Sci. Hortic. 2012, 144, 172-178. [CrossRef]

45. Cook, M.T.; Tzortzis, G.; Charalampopoulos, D.; Khutoryanskiy, V.V. Production and Evaluation of Dry Alginate-Chitosan Microcapsules as an Enteric Delivery Vehicle for Probiotic Bacteria. Biomacromolecules 2011, 12, 2834-2840. [CrossRef] [PubMed]

46. Mohan, C.; Ravishankar, C.; Lalitha, K.; Gopal, T.S. Effect of chitosan edible coating on the quality of double filleted Indian oil sardine (Sardinella longiceps) during chilled storage. Food Hydrocoll. 2012, 26, 167-174. [CrossRef]

47. Valencia-Chamorro, S.A.; Palou, L.; Del Río, M.A.; Pérez-Gago, M.B. Antimicrobial Edible Films and Coatings for Fresh and Minimally Processed Fruits and Vegetables: A Review. Crit. Rev. Food Sci. Nutr. 2011, 51, 872-900. [CrossRef]

48. Wang, S.Y.; Gao, H. Effect of chitosan-based edible coating on antioxidants, antioxidant enzyme system, and postharvest fruit quality of strawberries (Fragaria $\times$ aranassa Duch.). LWT 2013, 52, 71-79. [CrossRef]

49. Cruz-Romero, M.; Murphy, T.; Morris, M.; Cummins, E.; Kerry, J. Antimicrobial activity of chitosan, organic acids and nano-sized solubilisates for potential use in smart antimicrobially-active packaging for potential food applications. Food Control. 2013, 34, 393-397. [CrossRef]

50. Nowzari, F.; Shábanpour, B.; Ojagh, S.M. Comparison of chitosan-gelatin composite and bilayer coating and film effect on the quality of refrigerated rainbow trout. Food Chem. 2013, 141, 1667-1672. [CrossRef]

51. Moreira, M.D.R.; Pereda, M.; Marcovich, N.E.; Roura, S.I. Antimicrobial Effectiveness of Bioactive Packaging Materials from Edible Chitosan and Casein Polymers: Assessment on Carrot, Cheese, and Salami. J. Food Sci. 2010, 76, M54-M63. [CrossRef]

52. Vieira, J.M.; Flores-López, M.L.; de Rodríguez, D.J.; Sousa, M.C.; Vicente, A.A.; Martins, J.T. Effect of chitosan- Aloe vera coating on postharvest quality of blueberry (Vaccinium corymbosum) fruit. Postharvest Biol. Technol. 2016, 116, 88-97. [CrossRef]

53. Sohail, A.; Turner, M.S.; Coombes, A.; Bostrom, T.; Bhandari, B. Survivability of probiotics encapsulated in alginate gel microbeads using a novel impinging aerosols method. Int. J. Food Microbiol. 2011, 145, 162-168. [CrossRef]

54. Arnon, H.; Zaitsev, Y.; Porat, R.; Poverenov, E. Effects of carboxymethyl cellulose and chitosan bilayer edible coating on postharvest quality of citrus fruit. Postharvest. Biol. Technol. 2014, 87, 21-26. [CrossRef]

55. Kitinoja, L.; Kader, A. Measuring postharvest losses of fresh fruits and vegetables in developing countries. PEF White Pap. 2015, 15, 26. [CrossRef]

56. Khalifa, I.; Barakat, H.; El-Mansy, H.A.; Soliman, S.A. Effect of Chitosan-Olive Oil Processing Residues Coatings on Keeping Quality of Cold-Storage Strawberry (Fragaria ananassa. Var. Festival). J. Food Qual. 2016, 39, 504-515. [CrossRef]

57. Medina, E.; Caro, N.; Abugoch, L.; Gamboa, A.; Díaz-Dosque, M.; Tapia, C. Chitosan thymol nanoparticles improve the antimicrobial effect and the water vapour barrier of chitosan-quinoa protein films. J. Food Eng. 2019, 240, 191-198. [CrossRef]

58. Robledo, N.; Vera, P.; López, L.; Yazdani-Pedram, M.; Tapia, C.; Abugoch, L. Thymol nanoemulsions incorporated in quinoa protein/chitosan edible films; antifungal effect in cherry tomatoes. Food Chem. 2018, 246, 211-219. [CrossRef]

59. Shao, X.; Tu, K.; Tu, S.; Tu, J. A Combination of Heat Treatment and Chitosan Coating Delays Ripening and Reduces Decay in "Gala" Apple Fruit. J. Food Qual. 2012, 35, 83-92. [CrossRef]

60. Assis, O.B.G.; De Britto, D. Evaluation of the antifungal properties of chitosan coating on cut apples using a non-invasive image analysis technique. Polym. Int. 2011, 60, 932-936. [CrossRef]

61. Xing, Y.; Xu, Q.; Che, Z.; Li, W.; Li, X. Effects of chitosan-oil coating on blue mold disease and quality attributes of jujube fruits. Food Funct. 2011, 2, 466-474. [CrossRef]

62. Espinal-Hernández, P.; Colinas-León, M.T.; Ybarra-Moncada, M.C.; Méndez-Zúñiga, S.M.; Corrales-García, J. Postharvest effects of 1-mcp and chitosan/oleic acid coating in pitaya (Stenocereus griseus H.). J. Prof. Assoc. Cactus Dev. 2021, $23,43-57$.

63. Hernández-López, G.; Ventura-Aguilar, R.I.; Correa-Pacheco, Z.N.; Bautista-Baños, S.; Barrera-Necha, L.L. Nanostructured chitosan edible coating loaded with $\alpha$-pinene for the preservation of the postharvest quality of Capsicum annuum L. and Alternaria alternata control. Int. J. Biol. Macromol. 2020, 165, 1881-1888. [CrossRef]

64. Nascimento, J.I.G.; Stamford, T.C.M.; Melo, N.F.C.B.; Nunes, I.D.S.; Lima, M.A.B.; Pintado, M.M.E.; Stamford-Arnaud, T.M.; Stamford, N.P.; Stamford, T.L.M. Chitosan-citric acid edible coating to control Colletotrichum gloeosporioides and maintain quality parameters of fresh-cut guava. Int. J. Biol. Macromol. 2020, 163, 1127-1135. [CrossRef]

65. Braga, S.D.P.; Lundgren, G.A.; Macedo, S.A.; Tavares, J.F.; Vieira, W.A.D.S.; Câmara, M.P.S.; De Souza, E.L. Application of coatings formed by chitosan and Mentha essential oils to control anthracnose caused by Colletotrichum gloesporioides and C. brevisporum in papaya (Carica papaya L.) fruit. Int. J. Biol. Macromol. 2019, 139, 631-639. [CrossRef]

66. Braga, S.D.P.; Magnani, M.; Madruga, M.S.; Galvão, M.D.S.; de Medeiros, L.L.; Batista, A.U.D.; Dias, R.T.A.; Fernandes, L.R.; de Medeiros, E.S.; de Souza, E.L. Characterization of edible coatings formulated with chitosan and Mentha essential oils and their use to preserve papaya (Carica papaya L.). Innov. Food Sci. Emerg. Technol. 2020, 65, 102472. [CrossRef] 
67. Shah, S.; Hashmi, M.S.; Qazi, I.M.; Durrani, Y.; Sarkhosh, A.; Hussain, I.; Brecht, J.K. Pre-storage chitosan-thyme oil coating control anthracnose in mango fruit. Sci. Hortic. 2021, 284, 110139. [CrossRef]

68. Jaimun, R.; Sangsuwan, J. Efficacy of chitosan-coated paper incorporated with vanillin and ethylene adsorbents on the control of anthracnose and the quality of Nam Dok Mai mango fruit. Packag. Technol. Sci. 2019, 32, 383-394. [CrossRef]

69. Jaimun, R.; Sangsuwan, J.; Intipunya, P.; Chantrasri, P. Active wrapping paper against mango anthracnose fungi and its releasing profiles. Packag. Technol. Sci. 2018, 31, 421-431. [CrossRef]

70. Chávez-Magdaleno, M.E.; González-Estrada, R.R.; Ramos-Guerrero, A.; Plascencia-Jatomea, M.; Gutiérrez-Martínez, P. Effect of pepper tree (Schinus molle) essential oil-loaded chitosan bio-nanocomposites on postharvest control of Colletotrichum gloeosporioides and quality evaluations in avocado (Persea americana) cv. Hass. Food Sci. Biotechnol. 2018, 27, 1871-1875. [CrossRef]

71. Monzón-Ortega, K.; Salvador-Figueroa, M.; Gálvez-López, D.; Rosas-Quijano, R.; Ovando-Medina, I.; Vázquez-Ovando, A. Characterization of Aloe vera-chitosan composite films and their use for reducing the disease caused by fungi in papaya Maradol. J. Food Sci. Technol. 2018, 55, 4747-4757. [CrossRef] [PubMed]

72. Ventura-Aguilar, R.; Bautista-Baños, S.; Flores-García, G.; Zavaleta-Avejar, L. Impact of chitosan based edible coatings functionalized with natural compounds on Colletotrichum fragariae development and the quality of strawberries. Food Chem. 2018, 262, 142-149. [CrossRef]

73. Buchman, J.T.; Elmer, W.H.; Ma, C.; Landy, K.M.; White, J.C.; Haynes, C.L. Chitosan-Coated Mesoporous Silica Nanoparticle Treatment of Citrullus lanatus (Watermelon): Enhanced Fungal Disease Suppression and Modulated Expression of Stress-Related Genes. ACS Sustain. Chem. Eng. 2019, 7, 19649-19659. [CrossRef]

74. Lou, M.-M.; Zhu, B.; Muhammad, I.; Li, B.; Xie, G.-L.; Wang, Y.-L.; Li, H.-Y.; Sun, G.-C. Antibacterial activity and mechanism of action of chitosan solutions against apricot fruit rot pathogen Burkholderia seminalis. Carbohydr. Res. 2011, 346, 1294-1301. [CrossRef]

75. Meindrawan, B.; Ofe, O.; Susanto, C.S.; Ayman, A.; Mangindaan, D.; Kasih, T.P. Glucomannan-Beeswax-Chitosan Antimicrobial Edible Coating to Maintain the Storage Quality of Salak Fruit (Salacca zalacca). Macromol. Symp. 2020, 391, 1900164. [CrossRef]

76. Melo, N.F.C.B.; de Mendonçasoares, B.L.; Diniz, K.M.; Leal, C.F.; Canto, D.; Flores, M.A.; Tavares-Filho, J.H.D.C.; Galembeck, A.; Stamford, T.L.M.; Stamford-Arnaud, T.M.; et al. Effects of fungal chitosan nanoparticles as eco-friendly edible coatings on the quality of postharvest table grapes. Postharvest Biol. Technol. 2018, 139, 56-66. [CrossRef]

77. Oh, Y.A.; Oh, Y.J.; Song, A.Y.; Won, J.S.; Bin Song, K.; Min, S.C. Comparison of effectiveness of edible coatings using emulsions containing lemongrass oil of different size droplets on grape berry safety and preservation. LWT 2017, 75, 742-750. [CrossRef]

78. Buslovich, A.; Horev, B.; Shebis, Y.; Rodov, V.; Gedanken, A.; Poverenov, E. A facile method for the deposition of volatile natural compound-based nanoparticles on biodegradable polymer surfaces. J. Mater. Chem. B 2018, 6, 2240-2249. [CrossRef]

79. Hu, D.; Wang, H.; Wang, L. Physical properties and antibacterial activity of quaternized chitosan/carboxymethyl cellulose blend films. LWT 2016, 65, 398-405. [CrossRef]

80. Frazão, G.G.S.; Blank, A.F.; de Aquino Santana, L.C.L. Optimisation of edible chitosan coatings formulations incorporating Myrcia ovata Cambessedes essential oil with antimicrobial potential against foodborne bacteria and natural microflora of mangaba fruits. LWT 2017, 79, 1-10. [CrossRef]

81. Cui, H.; Yuan, L.; Li, W.; Lin, L. Edible film incorporated with chitosan andArtemisia annuaoil nanoliposomes for inactivation ofEscherichia coliO157:H7 on cherry tomato. Int. J. Food Sci. Technol. 2017, 52, 687-698. [CrossRef]

82. Li, Y.; Rokayya, S.; Jia, F.; Nie, X.; Xu, J.; Elhakem, A.; Almatrafi, M.; Benajiba, N.; Helal, M. Shelf-life, quality, safety evaluations of blueberry fruits coated with chitosan nano-material films. Sci. Rep. 2021, 11, 1-10. [CrossRef]

83. Rokayya, S.; Jia, F.; Li, Y.; Nie, X.; Xu, J.; Han, R.; Yu, H.; Amanullah, S.; Almatrafi, M.M.; Helal, M. Application of nano-titanum dioxide coating on fresh Highbush blueberries shelf life stored under ambient temperature. LWT 2021, 137, 110422. [CrossRef]

84. Ojeda, G.A.; Gorman, A.M.A.; Sgroppo, S.C.; Zaritzky, N.E. Application of composite cassava starch/chitosan edible coating to extend the shelf life of black mulberries. J. Food Process. Preserv. 2021, 45, e15073. [CrossRef]

85. Peralta-Ruiz, Y.; Tovar, C.D.G.; Sinning-Mangonez, A.; Coronell, E.A.; Marino, M.F.; Chaves-Lopez, C. Reduction of Postharvest Quality Loss and Microbiological Decay of Tomato "Chonto" (Solanum lycopersicum L.) Using Chitosan-E Essential Oil-Based Edible Coatings under Low-Temperature Storage. Polymers 2020, 12, 1822. [CrossRef]

86. Mohammadi, A.; Hashemi, M.; Hosseini, S.M. Postharvest treatment of nanochitosan-based coating loaded with Zataria multiflora essential oil improves antioxidant activity and extends shelf-life of cucumber. Innov. Food Sci. Emerg. Technol. 2016, 33, 580-588. [CrossRef]

87. Duran, M.; Aday, M.S.; Zorba, N.N.D.; Temizkan, R.; Büyükcan, M.B.; Caner, C. Potential of antimicrobial active packaging 'containing natamycin, nisin, pomegranate and grape seed extract in chitosan coating' to extend shelf life of fresh strawberry. Food Bioprod. Process. 2016, 98, 354-363. [CrossRef]

88. Khan, I.; Tango, C.N.; Chelliah, R.; Oh, D.-H. Development of antimicrobial edible coating based on modified chitosan for the improvement of strawberries shelf life. Food Sci. Biotechnol. 2019, 28, 1257-1264. [CrossRef] [PubMed]

89. Karagöz, S.; ; Demirdöven, A. Effect of chitosan coatings with and without Stevia rebaudiana and modified atmosphere packaging on quality of cold stored fresh-cut apples. LWT 2019, 108, 332-337. [CrossRef]

90. Pilon, L.; Spricigo, P.C.; Miranda, M.; De Moura, M.R.; Assis, O.B.G.; Mattoso, L.H.C.; Ferreira, M.D. Chitosan nanoparticle coatings reduce microbial growth on fresh-cut apples while not affecting quality attributes. Int. J. Food Sci. Technol. 2014, 50, 440-448. [CrossRef] 
91. Saki, M.; ValizadehKaji, B.; Abbasifar, A.; Shahrjerdi, I. Effect of chitosan coating combined with thymol essential oil on physicochemical and qualitative properties of fresh fig (Ficus carica L.) fruit during cold storage. J. Food Meas. Charact. 2019, 13, 1147-1158. [CrossRef]

92. Araújo, J.M.S.; De Siqueira, A.C.P.; Blank, A.F.; Narain, N.; de Aquino Santana, L.C.L. A Cassava Starch-Chitosan Edible Coating Enriched with Lippia sidoides Cham. Essential Oil and Pomegranate Peel Extract for Preservation of Italian Tomatoes (Lycopersicon esculentum Mill.) Stored at Room Temperature. Food Bioprocess. Technol. 2018, 11, 1750-1760. [CrossRef]

93. Benítez, S.; Achaerandio, I.; Pujola, M.; Sepulcre, F. Aloe vera as an alternative to traditional edible coatings used in fresh-cut fruits: A case of study with kiwifruit slices. LWT 2015, 61, 184-193. [CrossRef]

94. De Aquino, A.B.; Blank, A.F.; de Aquino Santana, L.C.L. Impact of edible chitosan-cassava starch coatings enriched with Lippia gracilis Schauer genotype mixtures on the shelf life of guavas (Psidium guajava L.) during storage at room temperature. Food Chem. 2015, 171, 108-116. [CrossRef] [PubMed]

95. Ban, Z.; Wei, W.; Yang, X.; Feng, J.; Guan, J.; Li, L. Combination of heat treatment and chitosan coating to improve postharvest quality of wolfberry (Lycium barbarum). Int. J. Food Sci. Technol. 2015, 50, 1019-1025. [CrossRef]

96. Breda, C.A.; Morgado, D.L.; De Assis, O.B.G.; Duarte, M.C.T. Effect of chitosan coating enriched with pequi (Caryocar brasiliense Camb.) peel extract on quality and safety of tomatoes (Lycopersicon esculentum Mill.) during storage. J. Food Process. Preserv. 2017, 41, e13268. [CrossRef]

97. Pagliarulo, C.; Sansone, F.; Moccia, S.; Russo, G.L.; Aquino, R.P.; Salvatore, P.; Di Stasio, M.; Volpe, M.G. Preservation of Strawberries with an Antifungal Edible Coating Using Peony Extracts in Chitosan. Food Bioprocess. Technol. 2016, 9, 1951-1960. [CrossRef]

98. Valenzuela, C.; Tapia, C.; López, L.; Bunger, A.; Escalona, V.; Abugoch, L. Effect of edible quinoa protein-chitosan based films on refrigerated strawberry (Fragaria $\times$ ananassa) quality. Electron. J. Biotechnol. 2015, 18, 406-411. [CrossRef]

99. Nia, A.E.; Taghipour, S.; Siahmansour, S. Pre-harvest application of chitosan and postharvest Aloe vera gel coating enhances quality of table grape (Vitis vinifera L. cv. 'Yaghouti') during postharvest period. Food Chem. 2021, 347, 129012. [CrossRef]

100. Xie, B.; Zhang, X.; Luo, X.; Wang, Y.; Li, Y.; Li, B.; Liu, S. Edible coating based on beeswax-in-water Pickering emulsion stabilized by cellulose nanofibrils and carboxymethyl chitosan. Food Chem. 2020, 331, 127108. [CrossRef] [PubMed]

101. Jung, J.; Deng, Z.; Zhao, Y. Mechanisms and performance of cellulose nanocrystals Pickering emulsion chitosan coatings for reducing ethylene production and physiological disorders in postharvest 'Bartlett' pears (Pyrus communis L.) during cold storage. Food Chem. 2020, 309, 125693. [CrossRef]

102. Muley, A.B.; Singhal, R.S. Extension of postharvest shelf life of strawberries (Fragaria ananassa) using a coating of chitosan-whey protein isolate conjugate. Food Chem. 2020, 329, 127213. [CrossRef]

103. Benhabiles, M.S.; Drouiche, N.; Lounici, H.; Pauss, A.; Mameri, N. Effect of shrimp chitosan coatings as affected by chitosan extraction processes on postharvest quality of strawberry. J. Food Meas. Charact. 2013, 7, 215-221. [CrossRef]

104. Perdones, Á.; Escriche, I.; Chiralt, A.; Vargas, M. Effect of chitosan-lemon essential oil coatings on volatile profile of strawberries during storage. Food Chem. 2016, 197, 979-986. [CrossRef] [PubMed]

105. Seyed, R.H.; Rastegar, S.; Faramarzi, S. Impact of edible coating derived from a combination of Aloe vera gel, chitosan and calcium chloride on maintain the quality of mango fruit at ambient temperature. J. Food Meas. Charact. 2021, 1-11. [CrossRef]

106. Yin, C.; Huang, C.; Wang, J.; Liu, Y.; Lu, P.; Huang, L. Effect of Chitosan- and Alginate-Based Coatings Enriched with Cinnamon Essential Oil Microcapsules to Improve the Postharvest Quality of Mangoes. Materials 2019, 12, 2039. [CrossRef]

107. Silva, G.M.C.; Silva, W.B.; Medeiros, D.B.; Salvador, A.R.; Cordeiro, M.H.M.; da Silva, N.M.; Santana, D.B.; Mizobutsi, G.P. The chitosan affects severely the carbon metabolism in mango (Mangifera indica L. cv. Palmer) fruit during storage. Food Chem. 2017, 237, 372-378. [CrossRef] [PubMed]

108. Awad, M.A.; Al-Qurashi, A.D.; Mohamed, S.A.; El-Shishtawy, R.M. Quality and biochemical changes of 'Hindi-Besennara' mangoes during shelf life as affected by chitosan, gallic acid and chitosan gallate. J. Food Sci. Technol. 2017, 54, 4139-4148. [CrossRef] [PubMed]

109. Jongsri, P.; Wangsomboondee, T.; Rojsitthisak, P.; Seraypheap, K. Effect of molecular weights of chitosan coating on postharvest quality and physicochemical characteristics of mango fruit. LWT 2016, 73, 28-36. [CrossRef]

110. Pagno, C.H.; Castagna, A.; Trivellini, A.; Mensuali-Sodi, A.; Ranieri, A.; Ferreira, E.A.; Rios, A.D.O.; Flôres, S.H. The nutraceutical quality of tomato fruit during domestic storage is affected by chitosan coating. J. Food Process. Preserv. 2017, 42, e13326. [CrossRef]

111. Ruzaina, I.; Rashid, N.A.; Jia, W.; Som, H.Z.M.; Seng, C.C.; Sikin, A.M.; Wahab, N.A.; Abidin, M.Z.; Zhong, F.; Li, Y. Effect of Different Degree of Deacetylation, Molecular Weight of Chitosan and Palm Stearin and Palm Kernel Olein Concentration on Chitosan as Edible Packaging for Cherry Tomato. J. Food Process. Preserv. 2016, 41, e13090. [CrossRef]

112. Mustafa, M.A.; Ali, A.; Manickam, S.; Siddiqui, Y. Ultrasound-Assisted Chitosan-Surfactant Nanostructure Assemblies: Towards Maintaining Postharvest Quality of Tomatoes. Food Bioprocess. Technol. 2014, 7, 2102-2111. [CrossRef]

113. Benhabiles, M.S.; Tazdait, D.; Abdi, N.; Lounici, H.; Drouiche, N.; Goosen, M.F.A.; Mameri, N. Assessment of coating tomato fruit with shrimp shell chitosan and N,O-carboxymethyl chitosan on postharvest preservation. J. Food Meas. Charact. 2013, 7, 66-74. [CrossRef]

114. Silva, W.B.; Silva, G.M.C.; Santana, D.B.; Salvador, A.R.; Medeiros, D.B.; Belghith, I.; da Silva, N.M.; Cordeiro, M.H.M.; Misobutsi, G.P. Chitosan delays ripening and ROS production in guava (Psidium guajava L.) fruit. Food Chem. 2018, 242, 232-238. [CrossRef] 
115. Khalifa, I.; Barakat, H.; El-Mansy, H.A.; Soliman, S.A. Preserving apple (Malus domestica var. Anna) fruit bioactive substances using olive wastes extract-chitosan film coating. Inf. Process. Agric. 2017, 4, 90-99. [CrossRef]

116. Gardesh, A.S.K.; Badii, F.; Hashemi, M.; Ardakani, A.Y.; Maftoonazad, N.; Gorji, A.M. Effect of nanochitosan based coating on climacteric behavior and postharvest shelf-life extension of apple cv. Golab Kohanz. LWT 2016, 70, 33-40. [CrossRef]

117. Chen, C.; Peng, X.; Chen, J.; Gan, Z.; Wan, C. Mitigating effects of chitosan coating on postharvest senescence and energy depletion of harvested pummelo fruit response to granulation stress. Food Chem. 2021, 348, 129113. [CrossRef]

118. Sharma, S.; Prasad, R.N.; Tiwari, S.; Chaurasia, S.N.S.; Shekhar, S.; Singh, J. Effect of chitosan coating on postharvest quality and enzymatic activity of eggplant (Solanum melongena L.) cultivars. J. Food Process. Preserv. 2021, 45, e15098. [CrossRef]

119. Sultan, M.; Hafez, O.M.; Saleh, M.A.; Youssef, A.M. Smart edible coating films based on chitosan and beeswax-pollen grains for the postharvest preservation of Le Conte pear. RSC Adv. 2021, 11, 9572-9585. [CrossRef]

120. Riaz, A.; Aadil, R.M.; Amoussa, A.M.O.; Bashari, M.; Abid, M.; Hashim, M.M. Application of chitosan-based apple peel polyphenols edible coating on the preservation of strawberry (Fragaria ananassa cv Hongyan) fruit. J. Food Process. Preserv. 2021, 45, e15018. [CrossRef]

121. Huang, Z.; Li, J.; Zhang, J.; Gao, Y.; Hui, G. Physicochemical properties enhancement of Chinese kiwi fruit (Actinidia chinensis Planch) via chitosan coating enriched with salicylic acid treatment. J. Food Meas. Charact. 2017, 11, 184-191. [CrossRef]

122. Lin, M.G.; Lasekan, O.; Saari, N.; Khairunniza-Bejo, S. The Effect of the Application of Edible Coatings on or before Ultraviolet Treatment on Postharvested Longan Fruits. J. Food Qual. 2017, 2017, 1-11. [CrossRef]

123. Meighani, H.; Ghasemnezhad, M.; Bakhshi, D. Effect of different coatings on post-harvest quality and bioactive compounds of pomegranate (Punica granatum L.) fruits. J. Food Sci. Technol. 2014, 52, 4507-4514. [CrossRef] [PubMed]

124. Gol, N.B.; Chaudhari, M.L.; Rao, T.V.R. Effect of edible coatings on quality and shelf life of carambola (Averrhoa carambola L.) fruit during storage. J. Food Sci. Technol. 2013, 52, 78-91. [CrossRef]

125. Shiri, M.A.; Ghasemnezhad, M.; Bakhshi, D.; Sarikhani, H. Effect of Postharvest Putrescine Application and Chitosan Coating on Maintaining Quality of Table Grape cv. "Shahroudi" during Long-Term Storage. J. Food Process. Preserv. 2012, 37, 999-1007. [CrossRef]

126. Shiri, M.A.; Bakhshi, D.; Ghasemnezhad, M.; Dadi, M.; Papachatzis, A.; Kalorizou, H. Chitosan coating improves the shelf life and postharvest quality of table grape (Vitis vinifera) cul-tivar Shahroudi. Turk. J. Agric. For. 2013, 37, 148-156. [CrossRef]

127. Shi, S.; Wang, W.; Liu, L.; Wu, S.; Wei, Y.; Li, W. Effect of chitosan/nano-silica coating on the physicochemical characteristics of longan fruit under ambient temperature. J. Food Eng. 2013, 118, 125-131. [CrossRef]

128. Li, J.; Yan, J.; Cao, J.; Zhao, Y.; Jiang, W. Preventing the wound-induced deterioration of Yali pears by chitosan coating treatments. Food Sci. Technol. Int. 2012, 18, 123-128. [CrossRef] 